\title{
The In Vitro Biosynthesis of Calcitonin
}

\author{
Nino Sorgente \\ Loyola University Chicago
}

Follow this and additional works at: https://ecommons.luc.edu/luc_diss

Part of the Medicine and Health Sciences Commons

\section{Recommended Citation}

Sorgente, Nino, "The In Vitro Biosynthesis of Calcitonin" (1969). Dissertations. 965.

https://ecommons.luc.edu/luc_diss/965

This Dissertation is brought to you for free and open access by the Theses and Dissertations at Loyola eCommons. It has been accepted for inclusion in Dissertations by an authorized administrator of Loyola eCommons. For more information, please contact ecommons@luc.edu. (c) $($ ) $\Theta \Theta$

This work is licensed under a Creative Commons Attribution-Noncommercial-No Derivative Works 3.0 License. Copyright (C) 1969 Nino Sorgente 


\section{THE IN VITRO BIOSYNTHESIS \\ OF CALCITONIN}

by

Nino Sorgente

\section{Library - - Loyola University Medical Center}

A Dissertation Submitted to the Faculty of the Graduate School of Loyola University in Partial Fulfillment of

the Requirements for the Degree of

. Doctor of Philosophy

June

1969 


\section{$\underline{\text { LIFE }}$}

Nino Sorgente was born in Aquara, Salerno (Italy), on January 8, 1940.

He graduated from the Torquato Tasso Classic Lyceum in Salerno, in 1958. He received a Bachelor of Arts degree from the University of Mlinois, Urbana, in June 1963. In June 1966, he received a Master of Science degree in Biology from DePaul University, Chicago, Mlinois.

In September 1966, Nino Sorgente began his graduate studies in the Department of Biochemistry and Biophysics, Loyola University Stritch School of Medicine under the guidance and counsel of Dr. Maurice V. L'Heureux. From September 1967 to June 1969 he served as a graduate teaching assistant in the Department. He has been a Trainee in a National Institute of Health Training Grant in Biochemistry since September 1966.

Nino Sorgente is the co-author of the following papers:

Salmon, M., Winn, H. E. and Sorgente, N. (1968). Sound Production and Associated Behavior in Triggerfishes. Pacific Science 22, 11. Cortelyou, J. R., McWhinnie, D. J. and Sorgente, N. (1967). Some Responses of Iguanid Lizards to Mammalian Parathyroid Extract. 


\section{Am. Zoologists 7, 719.}

Nino Sorgente is a member of the American Association for the Advancement of Science and the American Chemical Society and is an Associate Member of the Society of the Sigma Xi. 


\section{ACKNOWLEDGEMENTS}

The author wishes to express his sincere gratitude to $\mathrm{Dr}$.

Maurice V. L'Heureux for the help and time he so generously devoted to the completion of this work and the development of the ideas therein.

The author also wishes to express his thanks to all members of the Department of Biochemistry and Biophysics of Loyola University, in particular to Dr. Steven Keresztes-Nagy and Terrance Tanner for the amino acid analysis of calcitonin.

The author is very grateful to Mr. Salvatore P. Musillami of the Chicago Lamb Packing Company for providing the glands used in this investigation. 


\section{TABLE OF CONTENTS}

CHAPTER

PAGE

I

INTRODUCTION

Statement of the Problem . . . . . .

General Experimental Procedure . . . . .

Chemicals

Preparation of Incubation Media . . . . .

Tissue Preparation and Incubation ... . .

Extraction, Isolation and Purification of

Calcitonin

Determination of Serum Calcium . . . . .

Protein Analysis . . . . . . . . .

Measurement of Radioactivity . . . . .

Determination of Biological Activity . . . .

The Effect of the Addition of Glucose and Amino Acids of Calcitonin to the Incubation Medium on the Incorporation of Glycine-C14 in Thyroid Proteins . . . . . . . .

The Synthesis of Calcitonin in Krebs-Ringer Bicarbonate Buffer Containing Physiological Concentrations of Calcium . . . . . . . .

The Effect of High Calcium Concentrations on the Synthesis of Calcitonin by Ovine Thyroid Slices . . . . . . . . . . 


\section{TABLE OF CONTENTS CONTINUED}

CHAPTER

PAGE

The Effect of High Magnesium Concentrations on the Synthesis of Calcitonin by Ovine Thyroid Slices . . . . . . . . 56

The Effect of High Calcium Concentrations on the Release of Calcitonin from Ovine Thyroid Slices . . . . . . . . . .

Isolation and Purification of Calcitonin . . 66

Characterization of the Purified Calcitonin .. DISCUSSION . . . . . . . . . . . . 


\section{LIST OF TABLES}

TABLE

PAGE

I

Standard Curve Data for Calcium Determination . .

38

II

Standard Curve Data for Protein Determination . .

III

Effect of Glucose and Calcitonin Amino Acids on the Incorporation of Glycine-C-14 in the Proteins of Ovine Thyroid Slices . . . . . .

IV

Hypocalcemic Activity of Calcitonin Preparations Isolated from Unincubated Ovine Thyroid Glands and from Thyroid Slices Incubated in KrebsRinger Bicarbonate Buffer Containing Physiological Concentrations of Calcium . . . . . . . . .

Hypocalcemic Activity of Calcitonin Isolated from Ovine Thyroid Slices Incubated in Krebs-Ringer Bicarbonate Buffer Containing Physiological Calcium Concentrations. . . . . . . . . .

VI

Hypocalcemic Activity of Calcitonin Isolated from Ovine Thyroid Slices Incubated in Krebs-Ringer Bicarbonate Buffer Containing High Concentrations of Calcium. . . . . . . . . . . . . .

VII

The Effect of Vehicle (0.1 M Acetic Acid) for the Calcitonin Preparations on the Serum Calcium of Rats . . . . . . . . . . . . . .

VIII Hypocalcemic Activity of Calcitonin Preparations Isolated from Slices Incubated in Krebs-Ringer Bicarbonate Buffer Containing Physiological Concentrations of Magnesium . . . . . . .

IX

Hypocalcemic Activity of Calcitonin Preparations Isolated from Ovine Thyroid Slices Incubated in Krebs-Ringer Bicarbonate Buffer Containing High Concentrations of Magnesium . . . . . . 


\section{LIST OF TABLES CONTINUED}

TABLE

PAGE

$\mathrm{X}$

Hypocalcemic Activity of Calcitonin Preparations

Isolated from Slices Incubated in Krebs-Ringer

Bicarbonate Buffer Containing Physiological or

High Concentrations of Calcium and Magnesium . . 60

XI Summary of the Data on the Effect of Calcium

and Magnesium on the Synthesis of Calcitonin . . . 61

XII

Effect of Krebs-Ringer Bicarbonate Buffer Con-

taining Physiological and High Concentrations

of Calcium on the Plasma Calcium of Rats . . . .

XIII

Serum Calcium Changes Induced by the

Administration of Incubation Media Containing

Physiological Concentrations of Calcium . . . . .

XIV Serum Calcium Changes Induced by the

Administration of Incubation Media Containing

High Concentrations of Calcium . . . . . . . .

XV Hypocalcemic Activity of Lyophilized Fractions

from the Sephadex G-100 Column ........

XVI Hypocalcemic Activity of Lyophilized Fractions

from the Sephadex G-50 Superfine Column . . . 


\section{LIST OF FIGURES}

FIGURE

PAGE

1

Amino Acid Sequence of Porcine Alpha-

Calcitonin ....................

Flow Diagram for Fractionation and Purification of Calcitonin (2 pages) . . . . . . . 33-34

Standard Curve for Calcium Determination. . . .

Standard Curve for Protein Determination . . . .

Protein Content, Radioactivity and Elution

Pattern of Calcitonin Preparation from a Column of Sephadex G-100 . . . . . . .

6 Protein Content, Radioactivity and Elution Pattern of Hypocalcemic Activity from a Column of Sephadex G-50 Superfine . . . . . .

7 Reproduction of Thin Layer Chromatogram of Hypocalcemic Active Fractions . . . . . .

Reproduction of Two Dimensional Thin Layer Chromatogram of Hypocalcemic Active Material . 


\section{INTRODUCTION}

Calcium plays a critical role in a variety of essential processes such as excitation, contraction, blood clotting, enzymatic reactions and as a calcium phosphate complex it serves as the supporting component of the vertebrate system. McLean and Hastings (1935) have described the calcium concentration in body fluids as "one of nature's physiological constants". The interrelationships among the various calcium compartments and the controls operating to maintain the proper balance among them are poorly understood.

Bone represents by far the largest calcium compartment of the vertebrate system and it would be expected that any change in its state would be readily reflected in a change in the other compartments, especially blood. Then, the physiological regulation of blood calcium would be mediated mainly by those factors that influence the formation and resorption of bone, namely parathyroid hormone, calcitonin, and vitamin D. But there are other factors which have been implicated in the control of bone metabolism and plasma calcium. Thyroxine, corticoids, estrogens and growth hormone affect bone resorption, blood and urine calcium and phosphate (Nordin, 1966). The titers of these hormones do not change with experimentally induced changes in plasma calcium. It is not clear whether their action is a direct or an indirect 
one or whether they are of importance in the overall physiological maintenance of calcium homeostasis.

The importance of the parathyroid glands in the mediation of calcium homeostasis was recognized by MacCallum and Voegtlin (1908) who showed that the removal of the parathyroid glands caused a marked fall in serum calcium, and that the tetany associated with the hypocalcemia could be relieved by administration of calcium salts. An active parathyroid extract able to relieve tetany and restore to normal, the calcium and phosphate levels in the blood was prepared by Collip and coworkers who also developed a method for its bioassay (Collip, 1925; Collip et al. 1925; Collip and Clark, 1925a, b).

Albright and Reifenstein (1948) considered the primary effect of parathyroid hormone to be on the phosphate dissolved in the body fluids. The hormone would affect the phosphate in such a way as to make it more readily excreted by the kidneys with a resulting decrease in serum phosphate level. Resorption of the hydroxyapatite of bone would, therefore, increase resulting in an elevated serum calcium. According to this hypothesis the administration of parathyroid hormone results in a rise in serum calcium because of a primary effect on phosphate excretion.

In the second hypothesis developed by McLean and Urist (1955), 
bone was considered as the primary target of parathyroid hormone action with an indirect effect on the tubular reabsorption of phosphate. A negative feedback mechanism was proposed to regulate the hormone secretion. A low blood calcium titer would evoke an increased parathyroid hormone release, which would in turn effect calcium mobilization from bone to raise the serum calcium to the normal level; a high blood calcium titer would reduce the release of parathyroid hormone and the consequent bone resorption.

Rasmussen (1961) pointed out that a mechanism of blood calcium regulation based only on the parathyroid glands and their effect on bone would lead to wide fluctuations in blood calcium because of the slow and extended response of bone to parathyroid hormone by increasing tubular reabsorption of calcium and distal tubular secretion of phosphate. Rasmussen believed that the kidney may be responsible for the rapid control of small fluctuations in plasma calcium. Sanderson et al. (1960) observed that in intact dogs blood calcium would return to the initial level within a few hours after it had been raised by the administration of calcium or lowered by the administration of EDTA. In parathyroidectomized animals, however, it had not returned to the initial levels in 24 hours.

During perfusion experiments designed to test the hypothesis of 


\section{$-4-$}

McLean and Urist (1955), Copp and Davidson (1961) and Copp et al. (1961, 1962) obtained results similar to those of Sanderson. The feedback hypothesis could explain the difference in the response to hypocalcemia, consequent to EDTA administration, between the normal and parathyroidectomized animals. Hypocalcemia would stimulate parathyroid hormone synthesis and release, which in turn would increase calcium mobilization from bone, and the blood calcium would return to its initial level; in parathyroidectomized animals the absence of the parathyroid glands results in the observed lack of calcium return to its initial level. The time difference for calcium to return to its initial level observed between the normal and parathyroidectomized animals after induced hypercalcemia by administration of calcium chloride cannot be explained by the simple hypothesis that high levels of calcium suppress parathyroid hormone secretion. If this were so, the response should be similar in both the normal animal, where parathyroid hormone output has been inhibited, and in the parathyroidectomized animal, which lacks parathyroid hormone. Using the dog as the experimental animal, Copp et al. (1962) showed that during hypercalcemia the parathyroid glands produce a hypocalcemic factor, which he named calcitonin.

Hirsch; Gautier and Munson (1963) and MacIntyre, Foster and Kumar (1965) confirmed the existence of a hypocalcemic factor, but 
found that it was secreted by the thyroid glands. Hirsch et al. (1963) called the thyroid factor, thyrocalcitonin. Foster, MacIntyre and Pearse (1964) and Pearse (1965) suggested that thyrocalcitonin was synthesized by the parafollicular cells of the thyroid, and Pearse (1966) introduced the term $C$ cells ( $C$ for calcitonin) for these cells. Immunofluorescence studies (Bussolati, Carvalheira and Pearse, 1967) have demonstrated the presence of calcitonin in the $\mathrm{C}$ cells of the thyroid glands of the guinea-pig. The $\mathrm{C}$ cells of the thyroid glands are large, have an oval nucleus and contain spherical granules in their cytoplasm (Nonidez, 1932). Matsuzawa and Kurosumi (1967) in a study of the morphology of the $C$ cells demonstrated that the granules are released by hypercalcemic stimulation.

In a study of the embryology of the C cells, Carvalheira and Pearse (1967) established that these cells originate from the last pair of pharyngeal pouches and are present in all vertebrates except the cyclostomes. In bony fishes, elasmobranchs, amphibia, reptiles and birds, these cells remain separate from the thyroid glands and form the ultimobranchial bodies. It appeared that, at least, in some birds and reptiles some of these cells migrate to the thyroids as evidenced by extraction of calcitonin from both the ultimobranchial bodies and the thyroid. Copp et al. (1967) were able to extract calcitonin from the 
ultimobranchial bodies of chickens and Moseley et al. (1968) extracted calcitonin from the ultimobranchial bodies of the chicken, pigeon and the African skink (Mabuya striato). They found that in the chicken and skink most of the calcitonin was found in the ultimobranchial bodies, whereas in the pigeon it was found in equal amounts in both the ultimobranchial bodies and thyroid glands. Clark (1968) identified calcitonin in the ultimobranchial bodies of turtles (Crysemis picta and Pseudemys scripta).

Calcitonin seems to exist in at least four forms, designated alpha, beta, gamma and delta; the four calcitonins differ in their elution patterns on Sephadex gels (Gudmundsson, 1967) and the C-terminal proline of beta calcitonin does not have an amide group. The acalcitonin from porcine thyroid glands has been purified and its amino acid sequence determined (Potts et al. 1968; Neher et al. 1968). The sequence has been confirmed by the chemical synthesis of the polypeptide (Rittel et al. 1968). The polypeptide has 32 amino acids and a molecular weight of 3585 (Figure 1). The pure peptide has an activity of 200-250 Medical Research Council units/mg dry weight (Kahnt et al. 1968). One MRC unit is defined in terms of a Standard Preparation, 10 milliunits of which produce a $10 \%$ fall in plasma calcium when administered intravenously in a $150 \mathrm{gm}$ rat (Kumar et al. 1965). 
$-7-$

$\mathrm{S}-\mathrm{S} \longrightarrow$

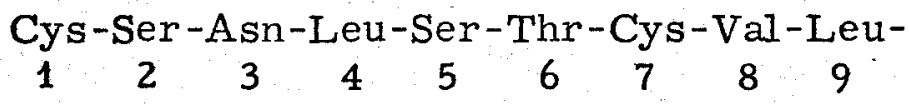

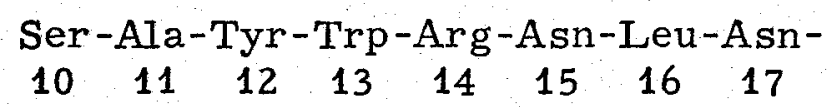

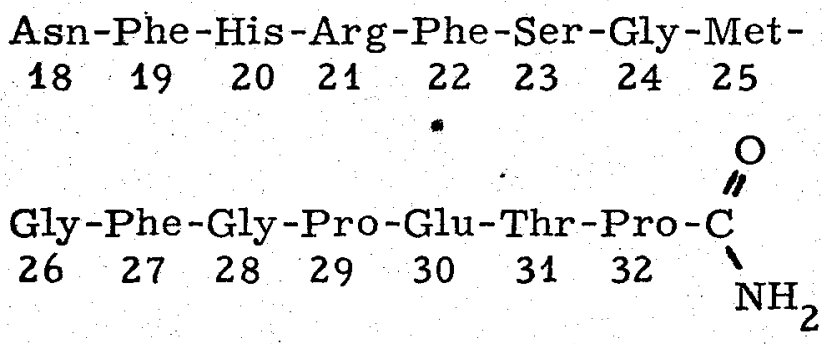

FIGURE 1. AMINO ACID SEQUENCE

OF PORCINE ALPHA-CALCITONIN

(Potts et al. 1968). 
The calcitonin peptide has several distinctive structural features (Potts et al. 1968). The single tyrosine and tryptophane residues are adjacent; the number of charged amino acids is quite low. There is a 1-7 intrachain disulfide bridge, providing a 23-membered ring at the amino-terminus. The carboxyl-terminal amino acid is prolinamide. The terminal disulfide group and the alpha-carboxyl amide are analogous structural features found in oxytocin and vasopressin. What portions of calcitonin are necessary for biological and immunological activity are not yet known; however, methionine (residue 25) may be alkylated or oxidized without loss of biological activity (Brewer et al. 1968). The serine, glycine and proline constitute $35 \%$ of the amino acid residues in the molecule; isoleucine is absent (Potts et al. 1967).

There seem to be some species differences with respect to the chemistry and biological activity of calcitonin. Tashjian and Munson (1965) found that antiserum to porcine calcitonin produced in rabbits neutralized pig and calf calcitonin but had no effect on the activity of calcitonin from rats, monkeys or man. Likewise, the difficulty in demonstrating hypocalcemic activity of porcine calcitonin in man may be due to differences in the calcitonin of the two species; in fact human calcitonin from $\mathrm{C}$ cell tumors has been isolated and the amino acid sequence determined (Neher et al. 1968) and it was found that even 
though the disulfide bridge between position 1 and 7 , and the $\mathrm{C}$-terminal proline amide are the same as in porcine alpha-calcitonin 18 amino acid residues are different throughout the molecule. Arginine and tryptophane are absent, lysine and isoleucine are found in position 18 and 27 respectively, and methionine changes its place from position 25 to 8. Pigeon calcitonin seems to be different from porcine calcitonin, since it has a different elution pattern than porcine calcitonin on Sephadex (Moseley et al. 1968). More evidence for species differences comes from the report that two porcine and one avian (chicken) calcitonin preparations, which had equal activities in the rat, were found to differ when tested in the mouse. One porcine and the avian preparation were ten and five times, respectively, more potent than the other porcine preparation (Parson and Reynolds, 1968).

Calcitonin acts on both bone and kidney. Kenny (1964) and Hirsch Voelkel and Munson (1964) showed that calcitonin decreases serum phosphate and that the administration of calcitonin was followed by a phosphaturia (Kenny and Heiskell, 1965; Milhaud, Moukhtar, Cherion and Perault, 1966; Robinson, Martin and MacIntyre, 1966). The renal effect, however, requires doses 10-100 times higher than those necessary to produce hypocalcemia (Russell and Fleish, 1967). The hypophosphatemia produced by calcitonin is not entirely due to an in- . 
creased excretion of phosphate, but also to increased phosphate deposition in bone; in fact, hypophosphatemia is still observed in nephrectomized rats (Robinson, Martin, Matthews and MacIntyre, 1967). The exact nature of the renal effect is not known, and it may be secondary to increased parathyroid hormone secretion (Stahl et al. 1966).

Several investigators have attempted to clarify the relationship between calcitonin and parathyroid hormone. Hirsch et al. (1964) reported that parathyroidectomy did not affect the hypocalcemic or the hypophosphatemic response to calcitonin. Gitelman et al. (1965) confirmed Hirsch's findings. Gudmundsson et al. (1966) observed that after parathyroidectomy, rats maintained on a normal diet did not exhibit the hypocalcemic effect of calcitonin but did exhibit the hypophosphatemic response. When the parathyroidectomized rats were maintained on a high calcium, low phosphate diet both the hypocalcemic and hypophosphatemic effects of calcitonin were observed. Milhaud et al. (1966), however, obtained results which showed that parathyroidectomy in rats maintained on a normal diet abolished only the hypophosphatemic effect. Stahl and Kenny (1967) have reported that thyroparathyroidectomy in the dog abolished the hypophosphatemic response of calcitonin, and calcitonin administration in the thyroparathyroidectomized dogs caused a relative hyperphosphatemia. On the other hand, the hyperphosphaturic effect in 
the rat is not abolished by thyroparathyroidectomy (Milhaud et al. 1966) or parathyroidectomy (Robinson, Martin and MacIntyre, 1966).

The hypocalcemic effect of calcitonin is due to its inhibitory action on calcium mobilization from bone. Friedman and Raisz (1965) studied the effect of calcitonin on isolated embryonic rat bones which had been pre-labeled in vivo with ${ }^{45} \mathrm{Ca}$. These investigators found that the addition of calcitonin to the culture medium decreased the release of ${ }^{45} \mathrm{Ca}$ from the bone; when both parathyroid hormone and calcitonin were added to the medium the effect was more pronounced. Histological examination showed that calcitonin diminished the fibroblastic and osteoclastic proliferation stimulated by parathyroid hormone. A similar, but less marked, change was observed in the culture to which parathyroid hormone was not added. Aliapoulios et al. (1966) demonstrated an inhibition of resorption in calvariae from 5-day old mice when calcitonin was added to the incubation medium. Calcitonin does not act as an inhibitor of parathyroid hormone. Reynolds et al. (1967) found that the changes in the osteocytes and osteoblasts brought about by parathyroid hormone or vitamin A could not be prevented by calcitonin, but calcitonin would inhibit the increase in osteoclasts. No changes were observed in hydroxyproline and hexosamine levels of mouse calvariae when calcitonin was added to the culture medium. In parathyroidecto- 
mized rats, Foster et al. (1966) noted a drop is osteoblasts after prolonged treatment with calcitonin.

The evidence for an effect of calcitonin on bone formation is unclear and contradictory. Raisz et al. (1967) observed no increase in the deposition of calcium from the medium into bone when calcitonin was added to the incubation medium of embryonic cultures of radii and ulnae. Gaillard (1967) observed an increase in osteoblasts in cultures treated with calcitonin, and Gaillard and Thesingh (1967) observed a net increase in the length and width of in vitro cultivated radius rudiments from 15-day old mouse embryos when calcitonin was added to the cultivating medium. These investigators also cultivated frontal bone from 18-day old chick embryos together with thyroid tissue of 8 day old chick embryos and observed an increase in the growth of the cultured bones. These observations indicate that the thyroid tissue of an 8-day old embryo releases some factor (probably calcitonin) that induces an increase in the width of bone as compared to controls. In contrast to Gaillard's results, Baylink, Morey and Rich (1969) using histological methods concluded that calcitonin decreases both the formation and resorption of bone. Goldhaber et al. (1968) reached the same conclusion from investigations which showed that calcitonin reduces the incorporation of tritiated proline into bone in culture systems. Nisbet 


\section{$-13-$}

and Nordin (1967), on the other hand, found that calcitonin did not change the uptake of proline-C-14 suggesting that bone formation is not affected.

Studies on the metabolism of bone are of very little help in establishing whether bone formation is affected by calcitonin. Bexter et al. (1968) reported that calcitonin increased the in vitro synthesis of glucosaminoglycan, indicating an increase in bone formation. Johnston and Deiss (1966) incubating calvariae from young adult $r$ ats showed that calcitonin decreased glucose utilization and lactate production. Insoluble hydroxyproline was also decreased; hexosamine was reduced but not significantly. Klein and Talmage (1967) demonstrated that calcitonin reduces the serum hydroxyproline and the wash hydroxyproline of peritaneal lavage. Martin, Robinson and MacIntyre (1966) and Aer (1968) found that calcitonin reduces urinary hydroxyproline excretion.

The increase in citric acid following the administration of parathyroid hormone has been well documented. Nisbet and Nordin (1967) in an in vitro system in which calvariae were incubated, studied the relation between calcitonin and citric acid. They found that less citric acid accumulated in the medium when parathyroid hormone and calcitonin were added to the cultures than when parathyroid hormone alone was added. The differences observed in the incubation medium were not 
reflected in the calvariae themselves.

The mode of action of calcitonin on bone is unknown. It does not act by inhibiting parathyroid hormone, since it acts in the absence of the parathyroid glands; it does not have any effect on ribonucleic acid (Gudmundsson et al. 1966; Tashjian, 1965). The hypothesis that it may increase the rate of the de novo synthesis of some enzyme does not have any experimental support.

Four possibilities have been considered which need not be exclusive of each other. First, the hormone both in vitro and in vivo has been shown to reduce the number of osteoblasts (Friedman and Raisz, 1965; Reynolds et al. 1967; Matrajt et al. 1967). Such changes in the cellular makeup of bone could account for the hypocalcemic effect of the hormone. No data is available on the time such changes occur after hormone administration; the studies available have been done after the animals had been chronically treated with calcitonin or after bone cultures had been incubated for days in a medium containing calcitonin. The hypocalcemic effect, however, is manifest 15 minutes after the hormone is administered. It is not known whether the cellular changes occur within such short a period of time or whether more subtle functional shifts occur at the molecular level and precede the morphological changes. 
A second hypothesis has been advanced by Wells and Lloyd (1968b) who found that imidazole produces a drop in blood calcium and antagonizes the hypercalcemic effect of parathyroid extract (Wells and Lloyd, 1968). Imidazole activates adenosine $3^{\prime}, 5^{\prime}$-phosphodiasterase, the enzyme which degrades cyclic $3^{\prime}, 5^{\prime}$-adenosine monophosphate. Previously. Wells and Lloyd (1967). showed that theophylline, which inhibits adenosine 3',5'-phosphodiasterase, produced hypercalcemia. Chase and Aurbach $(1967,1968)$ showed that parathyroid hormone stimulates the urinary excretion of cyclic adenylate which is dependent upon a direct action of the hormone on the kidneys. Wells and Lloyd (1968b) proposed that the level of cyclic AMP in bone cells mediates the rate of calcium mobilization and, secondarily, the level of serum calcium. Elevations of cyclic AMP level brought about by parathyroid hormone, theophylline or other drugs, increase the mobilization of calcium; a decrease in cyclic AMP, brought about by calcitonin, or imidazole, would decrease calcium mobilization. Substantiation of the hypothesis proposed by Wells and Lloyd can be found in the work of Chase and Aurbach (1968). These investigators have reported that parathyroid hormone increases adenyl cyclase activity in bone 3 to 5 fold; calcitonin, however, does not seem to affect cyclase activity. A third hypothesis involves the regulation of $\mathrm{pH}$ at the cellular 
level. It has long been known that parathyroid hormone increases acid production. Recently Nisbet and Nordin (1967) observed that citric acid levels are reduced in bone culture media when calcitonin is present, and the reduction is more marked when resorption is stimulated by parathyroid hormone. Calcitonin may increase the $\mathrm{pH}$ at the cellular level and decrease calcium mobilization.

Finally, Doty, Schofield and Robinson (1968) observed that acid phosphatase and ATPase are affected by calcitonin and parathyroid hormone in an opposite manner. Parathyroid extract increased the acid phosphatase of metaphyseal bone and the ATPase of osteoclasts, whereas calcitonin decreased the levels of these enzymes. These enzymes may be involved in the mechanism of action of calcitonin; acid phosphatase has been implicated as an important factor in the calcification process (Cartier, 1951). How these enzymes are related to bone formation and resorption is unknown.

Aliapoulios et al. (1966) have shown that extracts of human thyroid glands contain hypocalcemic activity and Barrett et al. (1968) has purified human calcitonin and found that it was stable and soluble at neutral $\mathrm{pH}$, whereas porcine calcitonin is not. In man calcitonin-like activity has been detected also in the thymus and parathyroid glands (MacIntyre, 1968). Abnormal calcitonin states are suspected to be involved in 
medullary carcinoma of the thyroid gland, pseudoparathyroidism and hyperparathyroidism. Increased calcium-lowering activity in either blood or tumor tissue or both have been found. Removal of the tumor results in decreased levels of circulating calcium lowering activity (Milhaud et al. 1968; Cunliffe et al. 1968; Melvin and Tashjian, 1968). The hypocalcemia associated with pseudohypoparathyroidism is believed to be caused by excessive secretion of calcitonin. Aliapoulios et al. (1966) and Tashjian et al. (1966) have shown that thyroid tissue from patients with pseudoparathyroidism contains approximately 100 times more calcitonin-like activity than normal thyroid tissue. Tetany and diffuse non-toxic goiter was found to be associated with increased calcitonin levels and thyroidectomy resulted in disappearance of the syndrome (Mazzuoli et al. 1966).

The therapeutic uses of calcitonin have not yet been explored in great detail. A serious hindrance to studies on the possible clinical application of calcitonin is the fact that normal man responds poorly to porcine calcitonin, at the present the main source of the hormone (Foster et al. 1967; Milhaud et al. 1965; Bell et al. 1966). Calcitonin elicits a weak hypocalcemic response in osteoporotic patients (Foster et al. 1968). In a patient with Paget's disease the administration of calcitonin was found to relieve the pain (Bijvoet and Jansen, 1964). 
The secretion of calcitonin in response to hypercalcemic states. has been well documented (Talmage et al. 1965; Toverod et al. 1966; Hirsch and Munson, 1966). In fact it was the result of perfusion studies with hypercalcemic blood that led Copp to postulate the presence of a hypocalcemic factor (Copp et al. 1962). There has been some question as to whether the hormone is secreted continuously or only in response to hypercalcemia. Talmage et al. (1965) postulated that calcitonin secretion occurred at normal plasma calcium levels. It has now been demonstrated that secretion of calcitonin occurs at normal and subnormal calcium levels (Deftos, Lee and Potts, 1968). It has also been established that the plasma calcium controls the levels of circulating calcitonin (Care et al. 1969).

\section{STATEMENT OF THE PROBLEM}

A study of the in vitro biosynthesis of calcitonin would be of value in attempting to define those conditions which in the organism control the synthesis and release of the hormone. There have been a number . of studies of the in vitro biosynthesis of polypeptide hormones. Bauer and Lazarow (1961) and Mallory et al. (1964) have reported the incorporation of radioactive amino acids into insulin using goosefish islet 
tissue and rat pancreas, respectively. More recently Steiner and Oyer (1967) and Steiner et al. (1967) using rat pancreas and islet cell tumor tissue demonstrated the incorporation of labeled amino acids into insulin and a precursor molecule. Takabatake and Sachs (1964) reported the in vitro biosynthesis of vasopressin by hypothalamic tissue. Wool et al. (1961) and Adiga et al. (1965) using various labeled amino acids demonstrated the in vitro biosynthesis of ACTH in anterior pituitary tissue. Wakabayashi and Tamaoki (1967) have reported the synthesis of LH by isolated anterior pituitary glands and have studied the effect of androgens on the synthesis.

By using the general experimental approach used for the biosynthesis of these polypeptide hormones we propose to synthesize calcitonin in an ovine thyroid slice system. Glycine-C-14 will be used as the tracer amino acid. Calcitonin titers in the blood are thought to be controlled by the levels of calcium; high levels of calcium inducing an increase and low levels inducing a decrease in the circulating calcitonin. In perfusion studies of the thyroid glands (Care et al. 1968; Lee et al. 1969) it has been shown that in vivo an increase in the calcium concentration of the perfusing medium resulted in increased circulating hypocalcemic activity.

Since in vivo the increased hypocalcemic activity, obtained in the 


\section{$-20-$}

high calcium perfusion studies, may have been the result of synthesis, release or both, we will study the effect of calcium on the synthesis and the effect of calcium on the release of the hormone in the in vitro synthesizing system to establish the role of these ions on calcitonin biosynthesis and release. Since it has been reported that magnesium affects the synthesis of parathyroid hormone (Buckle and Care, 1967), we will also study the effect of magnesium on the synthesis of calcitonin in the ovine thyroid slices. 


\section{CHAPTER II \\ MATERIALS AND METHODS}

\section{GENERAL EXPERIMENTAL PROCEDURE}

In the first part of this work our main purpose was to develop a system for the incorporation of glycine-C-14 into proteins of ovine thyroid slices, and more specifically the isolation, from the slices of calcitonin containing a radioactive amino acid. For this purpose ovine thyroid glands were obtained from the slaughterhouse as soon as possible after the animal was killed -- usually 10-20 minutes. The glands were placed in cold Krebs-Ringer bicarbonate buffer ${ }^{*}$ (pH 7.4) and were brought to the laboratory where they were dissected free from fat, connective tissue, and other adhering structures, then washed with cold Krebs-Ringer bicarbonate buffer ( $\mathrm{pH}$ 7.4) and cut with a StadieRiggs plastic tissue slicer into slices approximately $0.5-1.0 \mathrm{~mm}$ in thickness. The slices were then transferred into a series of $50 \mathrm{ml}$ Erlenmeyer flasks (approximately $2.0 \mathrm{gm}$ of slices per flask) containing $10 \mathrm{ml}$ of Krebs-Ringer bicarbonate buffer ( $\mathrm{pH} \mathrm{7.4)}$ to which was added

"The phrase "Krebs-Ringer bicarbonate buffer" whenever used later in this dissertation means a Krebs-Ringer bicarbonate buffer to which was added glucose $(320 \mathrm{mg} / 100 \mathrm{ml})$ and all the amino acids of calcitonin (20 $\mathrm{mg} /$ liter) with the exception of the one used as a tracer. 


\section{$-22-$}

glucose $(320 \mathrm{mg} / 100 \mathrm{ml})$ and all the amino acids of calcitonin $(20 \mathrm{mg} /$ liter) but the tracer. To each flask $2.5 \mu \mathrm{Ci}$ of the tracer amino acid were added. The incubation was carried out at $\mathrm{pH} 7.4$ in a constant shaker water bath at $37^{\circ} \mathrm{C}$ for 4 hours. Flasks which contained, in addition to the above, $1.0 \mathrm{ml}$ of $50 \%$ trichloroacetic acid served as controls. The incubation of the experimental flasks was terminated by the addition of $1.0 \mathrm{ml}$ of trichloroacetic acid to each flask.

The tissue slices after incubation were cut into small pieces with scissors and washed 10 times with cold acetone, 6 times with cold chloroform and again 10 times with cold acetone. The defatted tissue was then dried at room temperature and stored at $4^{\circ} \mathrm{C}$ until it was used.

The defatted tissue was then extracted with 10 volumes of 8.0 M urea $-0.1 \mathrm{~N}$ cysteine in $0.2 \underline{\mathrm{N}} \mathrm{HCl}$ for one hour at room temperature. The mixture was then squeezed through cheese cloth and washed with a volume of doubly-distilled water equal to that of the extraction solution. The filtrate and washings were combined and dialyzed against $0.1 \mathrm{M}$ acetate buffer ( $\mathrm{pH} 4.6)$ for 24 hours at $4^{\circ}$ C. To the dialysate was then added $3.0 \mathrm{M} \mathrm{NaCl}$ to a final concentration of $1.0 \mathrm{M}$. After standing for 72 hours at $4^{\circ} \mathrm{C}$ the precipitate was collected by centrifugation at $4^{\circ} \mathrm{C}$ at $1400 \mathrm{RCF}$ for 3 hours. The inactive precipitate was dis- 
carded and to the supernatant was added solid $\mathrm{NaCl}$ to a final concentration of $2.0 \mathrm{M}$. After 72 hours at $4^{\circ} \mathrm{C}$ the active precipitate was collected by centrifugation at $4^{\circ} \mathrm{C}$ at $1400 \mathrm{RCF}$ for 3 hours. The precipitate was then dried by lyophilization. The dried material was then purified on Sephadex columns.

Radioactivity and biological activity were measured at each step during the isolation. Biological activity was estimated by the hypocalcemic response to the injection of the test material in rats. Radioactivity was measured by liquid scintillation counting (Beckman LS 250 Liquid Scintillation Spectrometer) and total protein was determined by a modification of the Lowry method.

Once we were able to show that calcitonin is synthesized in vitro we studied the effect of high concentrations of calcium on the synthesis and the release of the hormone. The effect of high concentrations of magnesium on the synthesis of calcitonin was also studied. In this part of our investigation, the slices were incubated in normal, high calcium, or high magnesium media. To assess the extent of synthesis the slices were extracted and calcitonin isolated through the second sodium chloride precipitation step. The lyophilized material was dissolved in $0.1 \mathrm{M}$ acetic acid and injected intravenously into rats. The fall in serum calcium at 50 minutes was taken as the index of hypo- 
calcemic activity. The difference between the hypocalcemic activity of glands incubated in normal and high calcium or high magnesium was taken as representing the extent of synthesis. To measure the amount of released hormone at the end of the incubation the slices were removed and the media was injected into rats for bioassay; the fall in serum calcium 50 minutes after the administration of the calcitonin preparation was taken as the index of hypocalcemic activity released into the medium.

\section{CHEMICALS}

Acetic Acid, Glacial, J. T. Baker Chemical Company, No. 9507. Acetone, Mallinckrodt Chemical Works, AR No. 2440.

Amino Acids, L form, Mann Research Laboratories, Inc, , (M. A.)

Kit $00100-721$.

Albumin, Crystalline, Pentex, Inc., Lot No. 16.

Blue Dextran 2000, Pharmacia Fine Chemicals, Inc., No. 4474. Calcein Indicator, Fisher Scientific Company, No. C-566. Calcium Carbonate, Mallinckrodt Chemical Works, AR No. 4071. Calcium Chloride $-2 \mathrm{H}_{2} \mathrm{O}$, Mallinckrodt Chemical Works, AR No. 4160 . Chloroform, Mallinckrodt Chemical Works, AR No. 4440. Copper Sulfate $\cdot 5 \mathrm{H}_{2} \mathrm{O}$, Mallinckrodt Chemical Works, AR No. 4844. 
L-(+)-Cysteine Hydrochloride, Eastman Organic Chemicals, No. 2367. Dextrose, Anhydrous, Mallinckrodt Chemical Works, AR No. 4912. p-Dioxane, (stabilized), Mallinckrodt Chemical Works, AR No. 4937. Disodium Ethylenediamine Tetracetate, Versenes, Inc. Folin-Ciocalteu Phenol Reagent, Harleco.

Formic Acid 88\%, Mallinckrodt Chemical Works, AR No. 2592. ${ }^{14}$ C-Glycine (UL), Nuclear-Chicago, Batch No. 14, S.A. $108 \mathrm{mc} / \mathrm{mM}$, Tracerlab, Lot No. $78-81-2$, S.A. $70 \mathrm{mc} / \mathrm{mM}$. Hydrochloric Acid, J. T. Baker Chemical Company, No. 9535. Magnesium Sulfate $7 \mathrm{H}_{2} \mathrm{O}$, Mallinckrodt Chemical Works, AR No. 6056. Naphthalene, Matheson, Coleman and Bell, NX5.

Pentobarbital Sodium, Abbott Laboratories, No. 3117.

Potassium Phosphate Monobasic, Mallinckrodt Chemical Works, AR No. 7100 .

Potassium Sodium Tartrate, Mallinckrodt Chemical Works, AR No. 2367. Sephadex G-100, Pharmacia Fine Chemicals; Inc., No. 6164. Sephadex G-50, Superfine, Pharmacia Fine Chemicals, Inc., No. 5739. Sodium Acetate, Anhydrous, J. T. Baker Chemical Company, No. 3742. Sodium Bicarbonate, Mallinckrodt Chemical Works, AR No. 1412. Sodium Chloride, Mallinckrodt Chemical Works, AR No. 7581. Sodium Cyanide, J. T. Baker Chemical Company, No. 1144. Sodium Hydroxide, Mallinckrodt Chemical Works, AR No. 7708. 


\section{$-26-$}

Trichloroacetic Acid, Mallinckrodt Chemical Works, AR No. 2928. Urea, Mallinckrodt Chemical Works, AR No. 8648.

\section{PREPARATION OF INCUBATION MEDIA}

Krebs-Ringer bicarbonate buffer or a modification thereof served as the medium for the incubation. Normal composition of the KrebsRinger bicarbonate buffer is as follows:

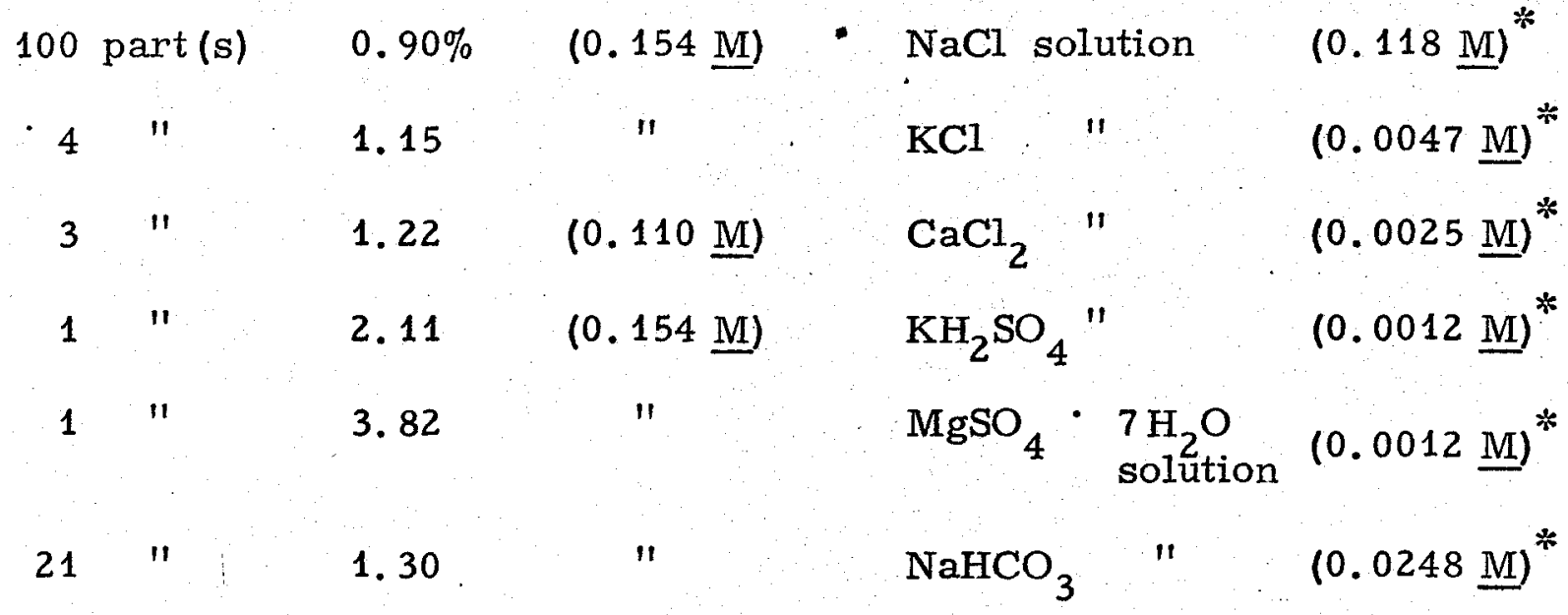

*Final concentration

Ionic strength $=0.1600$

$$
\begin{aligned}
& \left(\mathrm{Ca}^{++}=11.51 \mathrm{mg} / 100 \mathrm{ml}\right) \\
& \left(\mathrm{Mg}^{++}=3.7 \mathrm{mg} / 100 \mathrm{ml}\right)
\end{aligned}
$$

Twenty milligrams of each of the amino acids of calcitonin (with the exception of the tracer) and 3.2 grams of glucose were added to 
each liter of buffer. An oxygen-carbon dioxide (95\%:5\%) mixture was bubbled into the medium for fifteen minutes and the $\mathrm{pH}$ was adjusted to 7. 4 before it was used for incubation.

Modifications of the above mentioned Krebs-Ringer bicarbonate buffer were prepared to serve as high calcium and high magnesium media by increasing the calcium and magnesium ion concentration in such a way that calcium ion plus magnesium ion concentration were approximately equal. The final compositions of the modified buffer solution were as follows:

High-calcium medium

\begin{tabular}{|c|c|c|c|c|c|}
\hline 100 & $\operatorname{part}(s)$ & $0.90 \%$ & $(0.154 \underline{\mathrm{M}})$ & $\mathrm{NaCl}$ solution & $(0.1180 \mathrm{MI})^{*}$ \\
\hline 12 & $"$ & 1.22 & $(0.110 \underline{\mathrm{M}})$ & $\mathrm{CaCl}_{2}$ & $(0.0101 \mathrm{MI})^{*}$ \\
\hline 4 & $"$ & 1.15 & $(0.154 \underline{\mathrm{M}})$ & $\mathrm{KCl}$ & $(0.0047 \mathrm{M})^{*}$ \\
\hline 1 & "i & 2.11 & $" 1$ & $\mathrm{KH}_{2} \mathrm{SO}_{4}^{\prime \prime}$ & $(0.0012 \mathrm{M})^{*}$ \\
\hline 1 & $" 1$ & 3.82 & $"$ & $\mathrm{MgSO}_{4} \cdot \underset{\text { solution }}{7 \mathrm{H}_{2} \mathrm{O}}$ & $(0.0012 \mathrm{M})^{*}$ \\
\hline 21 & $"$ & 1. 30 & $" 1$ & $\mathrm{NaHCO}_{3}$ & $(0.0248 \underline{\mathrm{M}})^{*}$ \\
\hline
\end{tabular}

*

Final concentration
Ionic strength $=0.1838$

$$
\begin{aligned}
\left(\mathrm{Ca}^{++}\right. & =45.6 \mathrm{mg} / 100 \mathrm{ml}) \\
\left(\mathrm{Mg}^{++}\right. & =3.7 \mathrm{mg} / 100 \mathrm{ml})
\end{aligned}
$$


High-magnesium medium

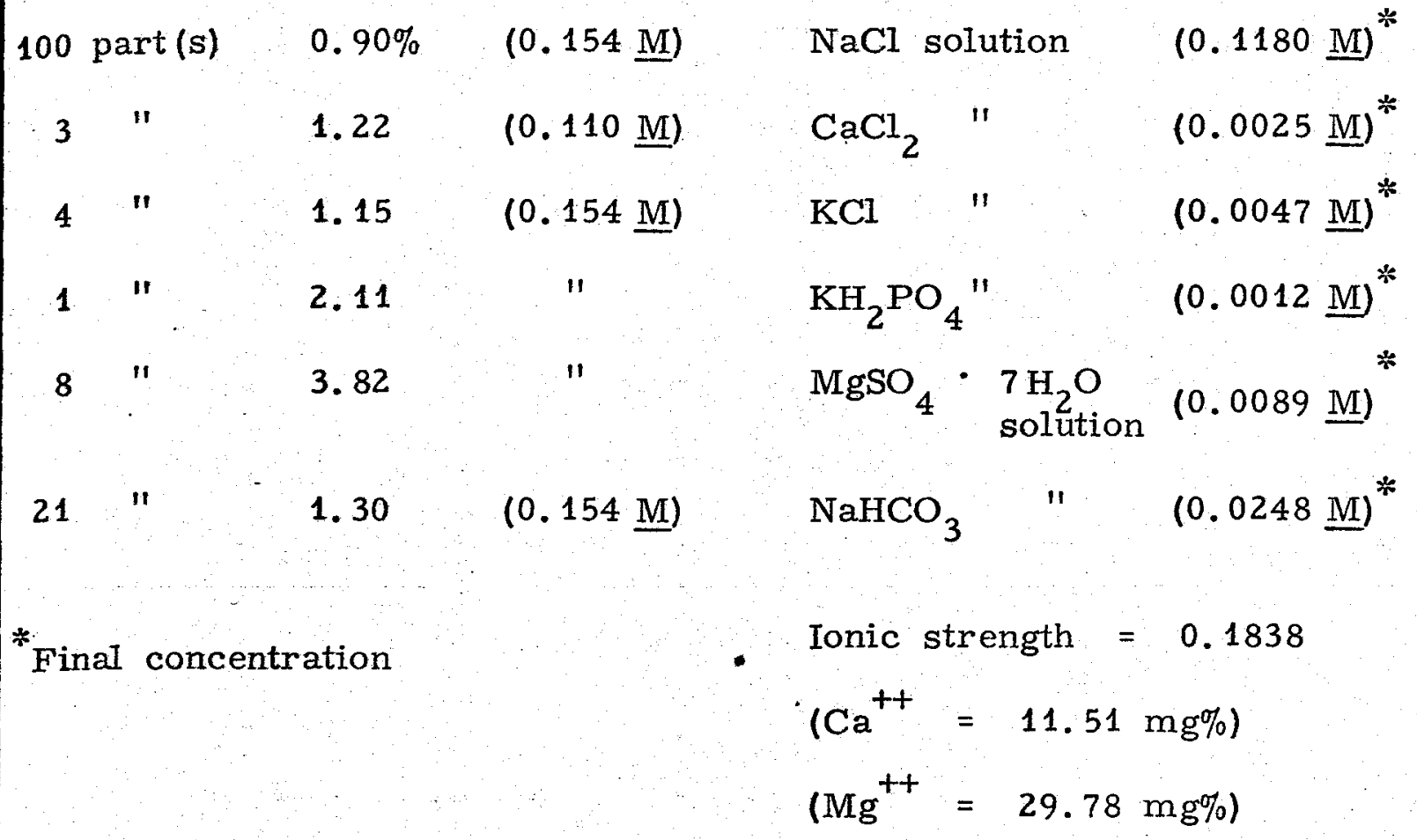

\section{TISSUE PREPARATION AND INCUBATION}

Ovine thyroid glands were obtained from the slaughterhouse (Chicago Lamb Packing Company, 3907 Halsted Street, Chicago, Illinois) between nine and ten o'clock in the morning and usually 10-20 minutes after sacrifice the glands with all adhering tissues were placed in cold Krebs-Ringer bicarbonate buffer $(\mathrm{pH} 7.4)$ and brought to the laboratory where they were dissected free from fat, connective and other adhering tissue and sliced in the cold into slices approximately $0.5-1.0 \mathrm{~mm}$ in thickness with a Stadie-Riggs tissue slicer. The elapsed time between 
sacrifice and incubation was usually four hours. The slices were weighed and about two grams were placed in each of a series of $50 \mathrm{ml}$ Erlenmeyer flasks. Each flask contained $10 \mathrm{ml}$ of Krebs-Ringer bicarbonate buffer and 2.5 $\mu \mathrm{Ci}$ of the labeled glycine. Some flasks contained, in addition to the above, $1.0 \mathrm{ml}$ of $50 \%$ trichloroacetic acid and served as controls. The gas phase for all incubations was air, and the incubations were carried out in a hood.

All incubations were carried out in a temperature controlled shaker water bath at $37^{\circ} \mathrm{C}$ for 4 hours.

Incubations were terminated by the addition to the flasks of $1.0 \mathrm{ml}$ of $50 \%$ TCA or by placing the slices into cold acetone.

To determine the effect of high calcium and high magnesium ions on synthesis and release of hormones, the incubations were carried out in buffer containing normal $\left(11.4 \mathrm{mg} \mathrm{Ca}^{++} / 100 \mathrm{ml} ; 3.7 \mathrm{mg} \mathrm{Mg}^{++} / 100\right.$ $\mathrm{ml}$ ), high calcium $\left(45.6 \mathrm{mg} \mathrm{Ca}^{++} / 100 \mathrm{ml} ; 3.7 \mathrm{mg} \mathrm{Mg}^{++} / 100 \mathrm{ml}\right)$ and high magnesium $\left(4.51 \mathrm{mg} \mathrm{Ca}{ }^{++} / 100 \mathrm{ml} ; 29.78 \mathrm{mg} \mathrm{Mg}^{++} / 100 \mathrm{ml}\right.$ ) concentrations. After incubation, aliquots of the high calcium medium were assayed for calcitonin activity to determine the release of the hormone from the slices. The slices were extracted for calcitonin through the second sodium chloride fractionation step. The material obtained was lyophilized, dissolved in $0.1 \mathrm{M}$ acetic acid buffer $(\mathrm{pH} 4.6)$ and assayed 
for hypocalcemic activity.

\section{EXTRACTION, ISOLATION AND PURIFICATION OF CALCITONIN}

When the incubations were terminated, the slices were minced with scissors and washed ten times with cold acetone, six times with cold chloroform and again ten times with cold acetone. The resulting lipidfree tissue was dried at room temperature (Rasmussen, 1959) and stored in a desiccator, unless immediately used. The acetone dried material was weighed and extracted with ten volumes of $8 \underline{M}$ urea -0.1 $\underline{\mathrm{N}}$ cysteine in $0.2 \mathrm{~N} \mathrm{HCl}$ (Rasmussen, 1964). The isolation and purification of the extract follows the procedure of Gudmundsson, MacIntyre and Soliman (1966). The mixture was stirred and allowed to stand for one hour at room temperature. It was then filtered through cheese cloth and the residue washed with doubly distilled water $110 \mathrm{ml} / \mathrm{gm}$ dry powder). The washings were combined with the filtrate and were dialyzed against $0.1 \underline{\mathrm{M}}$ sodium acetate buffer $(\mathrm{pH} 4.6)$ for 24 hours at $4^{\circ} \mathrm{C}$. The dialyzate was made up to $1.0 \mathrm{M}$ with respect to sodium chloride with $3.0 \mathrm{M} \mathrm{NaCl}$ and allowed to stand at $4^{\circ} \mathrm{C}$. After 72 hours the precipitate (inactive) was removed by centrifugation (1400 R.C.F.) for 3 hours at $4^{\circ} \mathrm{C}$. Solid sodium chloride was added to the supernatant to a final concentration of $2.0 \mathrm{M}$. After standing for a further 72 
hours at $4^{\circ} \mathrm{C}$ the precipitate was collected by centrifugation (1400 R.C.F.) for 3 hours at $4^{\circ}$ C. The precipitate was dried by lyophilization.

The dried precipitate was dissolved in $0.1 \mathrm{M}$ formic acid (18 mg/ $\mathrm{ml}$ ) and applied to a $2.5 \times 45 \mathrm{~cm}$ column of Sephadex G-100 and eluted with the same solvent. The transmission of the effluent at $280 \mathrm{~m} \mu$ was monitored with a Uvicord Absorptiometer and Recorder (LKB Instruments, Inc., Rockville, Maryland) and fractions were collected on a Gilson Fraction Collector $V^{15}$ (Gilson Medical Electronics, Middleton,

Wisconsin). Every fourth fraction was assayed for hypocalcemic activity. When one fraction containing hypocalcemic activity was found, the fractions preceding and following that fraction were assayed for hypocalcemic activity until one fraction on either side was found not to contain biological activity. The fractions containing hypocalcemic activity were pooled, lyophilized and stored at $4^{\circ} \mathrm{C}$ until used. The dried material was dissolved in 1.0 M formic acid and applied to a $0.9 \times 45 \mathrm{~cm}$ column of Sephadex G-50 superfine and eluted with a solution of $0.1 \underline{\mathrm{M}}$ formic acid $-1.0 \underline{\mathrm{M}}$ urea-0.2 $\underline{\mathrm{M}}$ sodium chloride. For biological activity the dried material was appropriately dissolved in $0.1 \mathrm{M}$ acetic acid and assayed. The fractions from the Sephadex G-50 column were scanned for hypocalcemic activity (vide supra); the 
fractions containing hypocalcemic activity were pooled, lyophilized and biological activity determined. A diagram of the fractionation and purification procedure is shown in Figure 2 .

To assess the purity of the fractions containing hypocalcemic activity, an aliquot from each fraction was chromatographed on thin layer cellulose sheets (Eastman Chromatogram Sheet 6065, cellulose with fluorescein indicator). For chromatography $50 \mu \mathrm{l}$ of each fraction was applied to a sheet and developed with the upper phase of a butanol: acetic acid: water $(4: 1: 5)$ system for 2.5 hours. The combined fractions were also chromatographed. Two dimensional chromatography was done on the combined fractions on cellulose thin layer sheets. $25 \mu 1$ of the combined fractions were applied on one corner of the sheet and developed in one direction with a butanol: acetic acid: water system and in the other direction with a propanol: water $(70: 30 \mathrm{v} / \mathrm{v})$ system. The migration of the sample applied was determined with a UV lamp.

To characterize further the biological active peptide $100 \mu l(4 \mu \mathrm{g}$ protein) of the combined fractions containing hypocalcemic activity from the Sephadex G-50 column were subjected to hydrolysis with $6.0 \mathrm{~N}$ $\mathrm{HCl}$ for 24 hours at $110^{\circ} \mathrm{C}$. The hydrolyzate was evaporated to dryness, redissolved in water and again evaporated to dryness; the dry material was dissolved in $0.01 \mathrm{~N} \mathrm{HCl}$ and analyzed for amino acids on 


\section{MINCED THYROID SLICES}

Extraction

(10 $\mathrm{x}$ with cold acetone

$6 \mathrm{x}$ with cold chloroform

$10 \times$ with cold acetone)

RESIDUE (dry at room temperature)

Extraction

10 volumes $8.0 \mathrm{M}$ urea $-0.1 \mathrm{~N}$ cysteine $-0.2 \mathrm{~N} \mathrm{HCl}$

1 hour at room temperature

Filter through cheese cloth

FILTRATE

1

RESIDUE

wash with 10

volumes water

\section{WASHINGS}

Dialyze against

$0.1 \mathrm{~N}$ acetate buffer (pH 4.6)

24 hours $4^{\circ} \mathrm{C}$

\section{DIALYSATE}

Add $3.0 \mathrm{M} \mathrm{NaCl}$

to make a $1.0 \mathrm{M}$

Allow to stand $\frac{1}{72}$ hr $4^{\circ} \mathrm{C}$

Centrifuge $3 \mathrm{hr} 1400 \mathrm{RCF}$

(Inactive) 
Figure 2, continued

$\begin{aligned} & \text { SUPERNATANT } \\ & \text { (Inactive) }\end{aligned}$
$\begin{aligned} & \text { Add solid } \mathrm{NaCl} \text { to make } 2.0 \mathrm{M} \\ & \text { Allow to stand } 72 \mathrm{hr} 4^{\circ} \mathrm{C} \\ & \text { Centrifuge } 3 \mathrm{hr} 1400 \mathrm{RCF}\end{aligned}$
$\begin{array}{ll}\text { PRECIPITATE } \\ \text { (active) }\end{array}$

\section{Lyophilize}

Dissolve in $0.1 \mathrm{MI}$ formic acid

Apply to Sephadex G-100

Elute with $0.1 \mathrm{M}$ formic acid.

\section{ACTIVE FRACTIONS}

\section{ACTIYE FRACTIONS}

Lyophilize. Dissolve in $1.0 \mathrm{M}$ formic acid Apply to Sephadex G-50 superfine column. Elute with $0.1 \mathrm{M}$ formic acid - $1.0 \mathrm{M}$ urea $0.2 \mathrm{~N} \mathrm{HCl}$

Thin layer chromatography

Amino acid analysis 
a TSM Amino Acid Autoanalyzer.

\section{DETERMINATION OF SERUM CALCIUM}

A method for determining ionizable calcium in serum by Ashby and Roberts was modified for use in this work. Blood samples were obtained from rats by tail bleeding. The tail was placed in warm water for about one minute, a quarter of one-half inch of the tail was cut with a sharp blade and the blood collected. The blood was placed in the refrigerator for about one hour before the clot was separated from the serum by centrifugation for two minutes in a Beckman Spinco Microfuge. Thirty microliter aliquots of serum were added to microtitrator cups; to each cup were added 150 microliters of 0.002 M EDTA, one drop (about 60 microliters) of properly diluted calcein indicator, one drop of $1 \%$ sodium cyanide solution, and one drop of 1.0

$\underline{N}$ sodium hydroxide. Titrations were performed with a Beckman Spinco Microtitrator filled with a $20.0 \mathrm{mg} \%$ standard calcium solution. A long wave ultraviolet lamp (Mineralight, Model SL 3660) was placed about 2 inches above the titration cup. The standard calcium solution was added with continuous stirring until a green fluorescence appeared. The calcium concentration of the sample is directly proportional to the difference in microliters of standard calcium solution required to 
titrate the sample and to titrate a water blank. A $12.0 \mathrm{mg} \%$ standard solution was titrated with each group of samples, and the calcium concentrations were calculated as follows:

$\mathrm{mg} \%$ calcium $=12.0 \mathrm{mg} \% \times$ microliters for unknown microliters for $12.0 \mathrm{mg} \%$ standard

microliters for unknown $=$ microliters of titrant required to titrate blank minus microliters of titrant required to titrate unknown sample

microliters for $12.0 \mathrm{mg} \%=$ microliters of titrant required to titrate standard blank minus microliters of titrant required to titrate $12.0 \mathrm{mg} \%$ standard

Figure 3 indicates the linear relationship between the microliters of titrant used and the concentration of calcium and the data for this standard curve appears in Table I. 


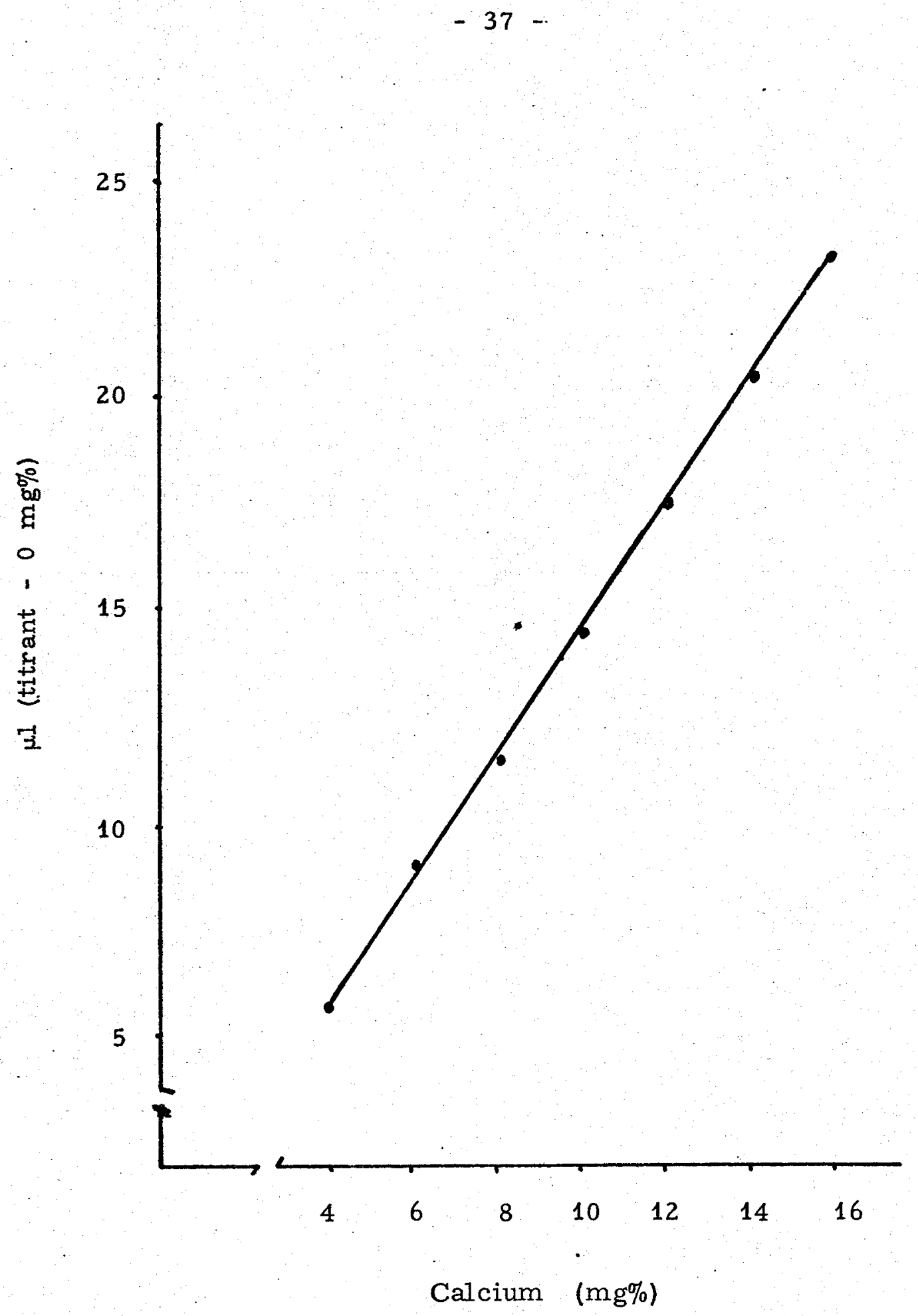

FIGURE-3. STANDARD CURVE FOR CALCIUM DETERMINATION 
TABLE I

Standard Curve Data for Calcium Determination

Calcium
$\mathrm{mg} \%$

$\mathrm{mg} \%$

0 Blank

4

6

8

10

12

14

16
No. of

Samples
Microliters

of Titrant

$$
29.31 \pm 0.13
$$

$23.62 \pm 0.26$

$20.29 \pm 0.13$

$17.66 \pm 0.19$

$14.69 \pm 0.08$

$11.59 \pm 0.13$

$8.77 \pm 0.15$

$5.67 \pm 0.13$
Microliters

(Titrant - $0 \mathrm{mg} \%$ ) 
Solutions

Calcein solution-concentrated: $0.25 \mathrm{gm}$ of powdered indicator was dissolved in $40 \mathrm{ml}$ of $1.0 \mathrm{~N} \mathrm{NaOH}$. The solution was diluted to $1000 \mathrm{ml}$ with doubly distilled $\mathrm{H}_{2} \mathrm{O}$.

Calcein Indicator solution: $0.5 \mathrm{ml}$ of the concentrated calcein solution was diluted to $25 \mathrm{ml}$ with doubly distilled water.

Calcium standard solution $(20 \mathrm{mg} \%): 0.2497 \mathrm{gm}$ of oven dried calcium carbonate was dissolved in $30 \mathrm{ml}$ of $2 \mathrm{~N} \mathrm{HCl}$ and diluted to $500 \mathrm{ml}$ with doubly distilled water. Working solutions were prepared from this stock solution.

Ethylenediaminotetraacetic acid: $187.5 \mathrm{mg}$ of $\mathrm{Na}_{2}$ EDTA was dissolved in $\mathrm{CO}_{2}$-free $\mathrm{H}_{2} \mathrm{O}$ to a total volume of $500 \mathrm{ml}$.

\section{$\underline{\text { PROTEIN ANALYSIS }}$}

Protein was determined according to the method of Lowry (1951) as modified by Oyama and Eagle (1956). One milliliter of reagent " $\mathrm{C}$ " was placed in each of $9 \times 75 \mathrm{~mm}$ test tube. To each tube was added $200 \mu 1$ of sample (water for the blanks), the contents were mixed and allowed to stand for 10 minutes. Then $0.1 \mathrm{ml}$ of Folin-Ciocalteu reagent was added to each tube with mixing. The tubes were allowed to stand for 30 minutes and the transmittance read at $750 \mathrm{~m} \mu$ on a 
Beckman DU spectrophotometer. A standard curve was prepared following the same procedure using bovine serum albumin as standard. The data for the calibration curve are given in Table $I$ and the standard curve appears in Figure 4.

\section{Calculations}

The transmittance is converted to optical density and the density. of the reagent blank is subtracted from that of the experimental and standard tubes. The concentration of the unknown is calculated using the formula:

$$
\frac{{ }^{O}}{O_{s}} \times \text { (concentration of standard) } \times 5=\begin{gathered}
\text { protein } / \mathrm{ml} \text { of unknown } \\
\text { sample }
\end{gathered}
$$

\section{Solutions}

Reagent A: $20 \mathrm{gm}$ of $\mathrm{Na}_{2} \mathrm{CO}_{3}, 4 \mathrm{gm}$ of $\mathrm{NaOH}$ and $200 \mathrm{mg}$ of $\mathrm{KNaC}_{4} \mathrm{H}_{4} \mathrm{O}_{6} \cdot 4 \mathrm{H}_{2} \mathrm{O}$ were dissolved in one liter of doubly distilled water. Reagent B: $\quad 5 \mathrm{gm}$ of $\mathrm{CuSO}_{4} \cdot 5 \mathrm{H}_{2} \mathrm{O}$ were dissolved in one liter of doubly distilled water.

Folin-Ciocalteu Reagent: Folin-Ciocalteu Reagent was obtained commercially from Fisher Scientific Company and diluted with doubly distilled $\mathrm{H}_{2} \mathrm{O}$. The dilution (usually 5:7) giving the highest optical 
TABLE II

Standard Curve Data for Protein Determination

\begin{tabular}{ccc}
\hline & $\begin{array}{c}\text { No of } \\
\text { Determinations }\end{array}$ & OD $_{750}$ \\
Albumin $(\mu g)$ & 6 & 0.0873 \\
5 & 6 & 0.1634 \\
10 & 6 & 0.1634 \\
20 & 5 & 0.4036 \\
30 & 6 & 0.5393 \\
40 & 5 & 0.6025 \\
50 & 6 & \\
\hline
\end{tabular}


$-42-$

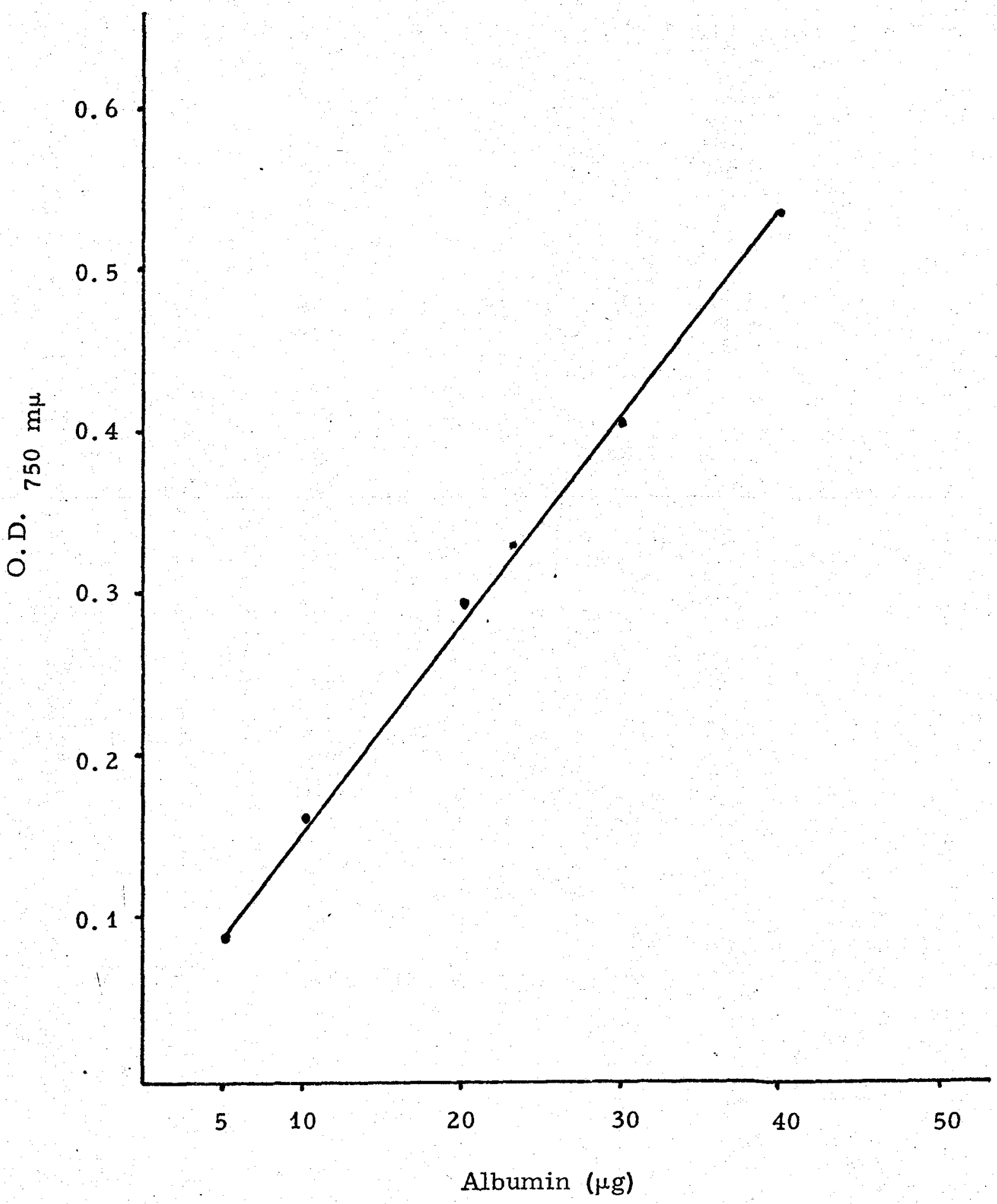

FIGURE 4. STANDARD CURVE FOR PROTEIN DETERMINATION 
density that was stable for two hours was selected.

Reagent $C$ : Fifty parts of reagent $A$ and one part of reagent $B$ were mixed fresh on the day of use.

\section{Measurement of Radioactivity}

A Beckman LS-250 Liquid Scintillation Spectrometer was used for all the radioactivity determinations. Samples were counted in twentytwo milliliter low potassium-40 content glass vials with tin-foil lined plastic screw caps. Ten milliliters of the desired scintillation fluid were placed in each vial. To the scintillation fluid was added an appropriate amount of the sample and the sample was counted five times for five minutes each time.

The scintillation fluid was prepared by dissolving $4.0 \mathrm{gm}$ of PPO and $100.0 \mathrm{gm}$ of naphthalene in $\mathrm{p}$-dioxane and made up to the volume of one liter.

\section{DETERMINATION OF BIOLOGICAL ACTIVITY}

Male Holtzman rats weighing from 100 to 110 grams (Holtzman Company, Madison, Wisconsin) were kept in the laboratory and fed standard rat chow until they reached a weight of 140 to 170 grams at which time they were used for determination of biological activity of calcitonin preparations. 
The animals were anesthetized with sodium pentobarbital injected intraperitoneally at a dose of $5 \mathrm{mg}$ per 100 grams of body weight. A blood sample was collected from the tail.. The animal was placed on an operating board, an incision was made along the thigh to expose the femoral vein. $250 \mu 1$ of calcitonin preparation, or vehicle, was injected into the vein using a Hamilton syringe of appropriate size, except for the experiments to determine the effect of calcium on calcitonin release from the thyroid slices when $150 \mu l$ of incubation medium or buffer was injected into the vein. The incision was then closed with wound clips. After fifty minutes, while the animal was still under anesthesia, another blood sample was collected.

The blood was allowed to remain in the refrigerator for about one hour for clot formation. It was then centrifuged for two minutes to separate the serum. The serum was analyzed for calcium and the difference between the calcium at zero time and fifty minutes was used as an index of the effect of the material administered. 


\section{CHAPTER III \\ EXPERIMENTAL RESULTS}

The experimental portion of this work comprises two parts. These include the biosynthesis and purification of calcitonin, and the bioassay of the synthesized material. In the biosynthesis and purification studies, a system for the incorporation of glycine-C-14 into ovine thyroid slices was developed. The slices were then subjected to isolation and purification procedures to obtain a highly purified calcitonin preparation. The medium used for the incubation was Krebs-Ringer bicarbonate buffer, $\mathrm{pH}$ 7.4, to which was added glucose and the amino acids of calcitonin to stimulate protein synthesis and calcitonin synthesis in particular.

The second part of this work comprised the study of the effects of high calcium and high magnesium concentrations on the synthesis and release of calcitonin from the thyroid slices. This was done in an attempt to define the conditions which control the synthesis and release of the hormone.

The Effect of the Addition of Glucose and Amino Acids of Calcitonin to the Incubation Medium on the Incorporation of Glycine-C-14 in Thyroid Proteins.

One gram of ovine thyroid slices was incubated with $1.25 \mu \mathrm{c}$ of 
glycine-C-14 (UL) in $25 \mathrm{ml}$ Erlenmeyer flasks containing $5.0 \mathrm{ml}$ of buffer. The incubations were carried out at $37^{\circ} \mathrm{C}$ for 4 hours in a constant temperature shaking water bath. The gas phase was air. The incubations were terminated with the addition of one milliliter of $50 \%$ trichloroacetic acid. The slices were homogenized in distilled water and $100 \mu l$ of the homogenate was counted in a liquid scintillation mixture containing 6\% Cab-O-Sil (Packard Instruments Company, Downers Grove, mlinois). The protein in the homogenate was determined and the radioactivity expressed in disintegrations per minute per milligram protein.

The data on the effect of glucose and the amino acids of calcitonin are presented in Table III. It is readily evident that the radioactivity represents true incorporation since the slices in the "killed" flasks show negligible radioactivity. It is also evident that glucose markedly stimulates the incorporation of glycine-C-14 into the thyroid tissue, the increase above the basal level is approximately $200 \%$. The addition of the calcitonin amino acids alone has no significant effect on the isotope incorporation. The addition of both glucose and amino acids increases incorporation with respect to the basal level (102\%). However, a decrease in the incorporation of the radioactive label is observed when compared to the medium with glucose alone. 
Effect of Glucose and Calcitonin Amino Acids on the Incorporation of Glycine-C-14 in the Proteins of Ovine Thyroid Slices

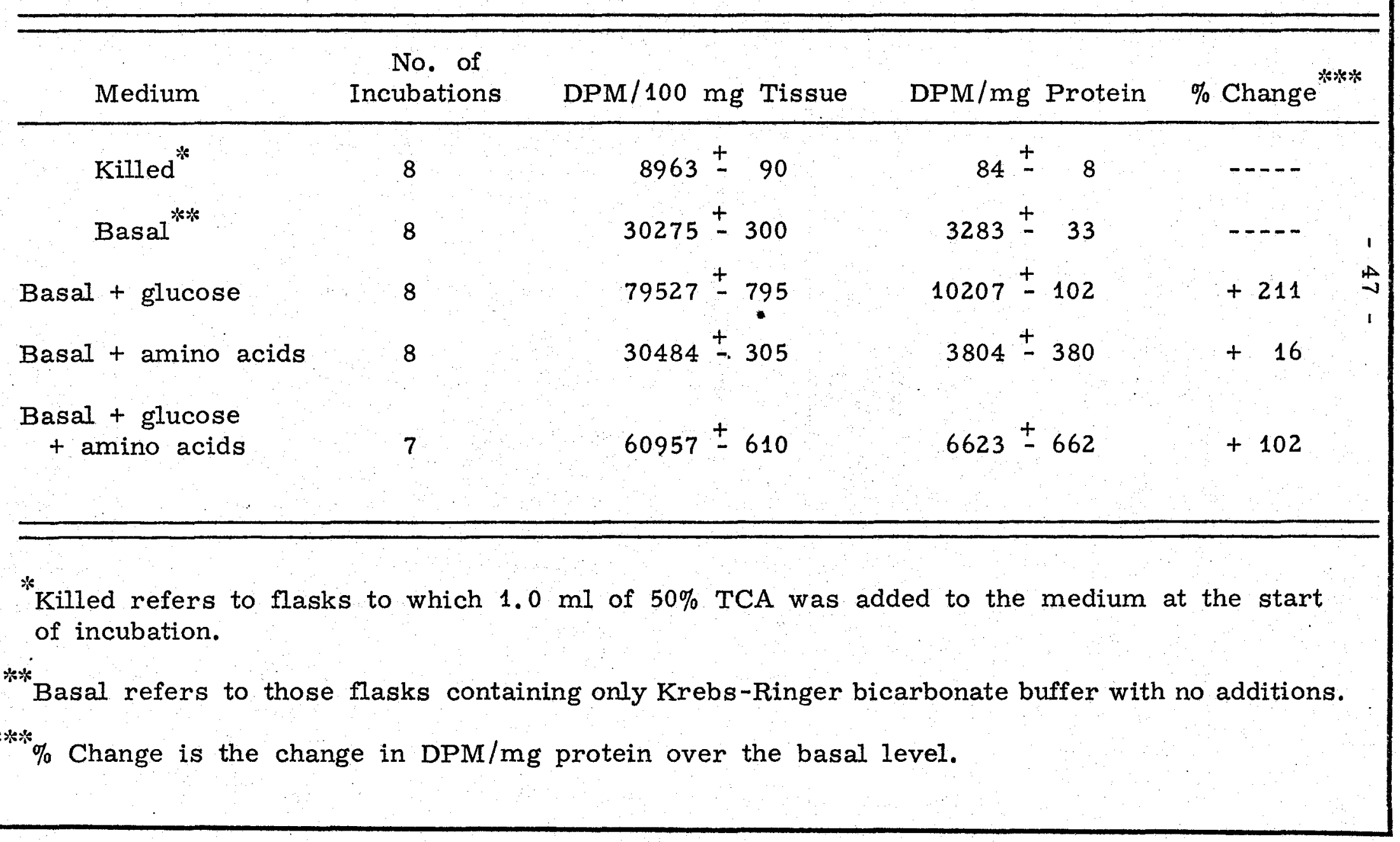


In all subsequent incubations we used the medium to which glucose and the amino acids of calcitonin were added. We believe that the decrease in incorporation observed with this medium was due to a decrease in the incorporation of label into proteins requiring other amino acids besides those of calcitonin. The lack of these amino acids depressed the synthesis of those proteins requiring other amino acids in addition to those added, whereas the synthesis of those proteins and polypeptides made up only of the amino acids of calcitonin would be accelerated. When glucose alone was added the synthesis of many small peptides would result with very few complete proteins formed, since the only source of essential amino acids would be the pool of amino acids present in the slices and from the breakdown of other proteins.

\section{The Synthesis of Calcitonin in Krebs-Ringer Bicarbonate Buffer Con-}

\section{taining Physiological Concentrations of Calcium.}

To determine whether calcitonin was being synthesized at physiological concentrations of calcium, ovine thyroid slices were incubated in Krebs-Ringer bicarbonate buffer containing $11.5 \mathrm{mg}$ calcium per $100 \mathrm{ml}$ of buffer. 18 to 20 grams of slices were found necessary to extract an amount of calcitonin sufficient for the assay of hypocalcemic activity. 
For this experiment, 20 grams of slices were incubated in KrebsRinger bicarbonate buffer in 2.0 gram quantities in $50 \mathrm{ml}$ Erlenmeyer flasks containing $10 \mathrm{ml}$ of buffer. The incubations were carried out in an atmosphere of air at $37^{\circ} \mathrm{C}$ for 4 hours and were terminated with the addition of $1.0 \mathrm{ml}$ of $50 \%$ trichloroacetic acid to each flask.

The incubated glands and 20 grams of unincubated glands were extracted and calcitonin was isolated through the second sodium chloride precipitation step. The active precipitate was lyophilized, dissolved in $0.1 \underline{\mathrm{M}}$ acetic acid and the hypocalcemic activity assayed in 140-170 gram Holtzman rats. The rats were fasted 18 hours before assay. Each rat received intravenously $250 \mu \mathrm{l}$ of the calcitonin preparation which contained $125 \mu \mathrm{g}$ of lyophilized material. The calcitonin preparations were analyzed for protein content and the change in serum calcium was expressed as $\triangle \mathrm{Ca}$ per $10 \mu \mathrm{g}$ protein. Comparison of the decrease in serum calcium (Table IV) obtained with the calcitonin preparation obtained from incubated and unincubated glands shows that only a small difference statistically not significant $(0.11 \mathrm{mg} \% \mathrm{Ca})$ exists. This finding is in accord with in vivo observations which indicate that at physiological serum calcium concentration only small amounts of calcitonin are present in the circulation. 


\section{TABLE IV}

Hypocalcemic Activity of Calcitonin Preparations Isolated from Unincubated Ovine Thyroid Glands and from Thyroid Slices Incubated in Krebs-Ringer Bicarbonate Buffer Containing Physiological Concentrations of Calcium.

\section{UNINCUBATED GLANDS}

Animal

No.

\begin{tabular}{ccccc}
\hline 1 & 11.46 & 11.27 & -0.19 & -0.22 \\
2 & 11.52 & 10.44 & -1.08 & -1.23 \\
3 & 11.78 & 11.47 & -0.31 & -0.36 \\
4 & 11.44 & 10.73 & -0.71 & -0.81 \\
5 & 11.86 & 11.31 & -0.56 & -0.64 \\
\hline Mean - s.e. & & & & $-0.65 \pm 0.17$ \\
\hline
\end{tabular}

$\mathrm{Ca} \mathrm{mg} \%$

$t_{0} \quad t_{50} \quad \Delta \mathrm{Ca} \mathrm{mg \%}$

$\triangle \mathrm{Ca} / 10 \mu \mathrm{g}$ $\mathrm{mg} \% /$ Protein

\section{INCUBATED GLANDS}


The Effect of High Calcium Concentrations on the Synthesis of Calcitonin by Ovine Thyroid Slices.

Since calcitonin titers in the circulation seem to be controlled by the serum calcium concentration, and since at physiological concentrations of calcium no net synthesis was observed, it became apparent that if a significant amount of synthesis was to be observed, the calcium concentration in the incubation media would have to be increased. KrebsRinger bicarbonate buffer was prepared such that the calcium ion concentration was $45.6 \mathrm{mgs}$ per $100 \mathrm{ml}$ of buffer. To eliminate any variation which may have existed in the content of calcitonin of the glands due to the source and age of the animals, food ingested and season of sacrifice, incubations in buffer containing physiological and high concentrations of calcium were carried on at the same time.

After incubation the glands were pooled and calcitonin isolated through the second sodium chloride precipitation step. The precipitate was lyophilized, dissolved in $0.1 \mathrm{M}$ acetate buffer and its hypocalcemic activity assayed in 140-170 gram rats.

When the amount of calcitonin is determined, the preparation obtained from glands incubated in Krebs-Ringer bicarbonate buffer containing high concentrations of calcium $(45.6 \mathrm{mg} \%)$ show higher hypocalcemic activity than those preparations obtained from glands incubated in Krebs- 
Ringer buffer containing physiological concentrations of calcium (11.5 $\mathrm{mg} \%$ ) (Tables $\mathrm{V}$ and VI).

The net effect has in each case been calculated by adding to the effect of the administered preparation the effect of the vehicle alone that of 0.1 M acetic acid. As shown in Table VII, the vehicle alone raised the serum calcium by an average of $0.55 \mathrm{mg}$. The decrease in serum calcium is greater for the three preparations obtained from the glands incubated in buffer containing high calcium concentrations than for those incubated in buffer containing physiological calcium concentrations. The fall in serum calcium is $4.9 \%, 5.0 \%$ and $6.2 \%$ for the three preparations respectively.

A comparison of the hypocalcemic activity of the calcitonin preparations obtained from slices incubated in buffer containing physiological concentrations of calcium with preparations obtained from glands incubated in buffer containing high concentrations of calcium shows that the difference of the means of preparations 2 and 3 is statistically significant at the $5 \%$ level or less, as evaluated by a Student's " $t$ " Test. The significance of the difference of the means of preparation 1 is questionable and lies between the 10 and $5 \%$ level.

These findings support the in vivo studies which show that hypercalcemia increases the circulating calcitonin activity. 


$$
-53-
$$

\section{TABLE V}

Hypocalcemic Activity of Calcitonin Isolated from Ovine

Thyroid Slices Incubated in Krebs-Ringer Bicarbonate

Buffer Containing Physiological Calcium Concentrations

Preparation Animal

No.

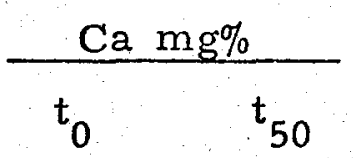

11.52

12.13

11. 88

12.13
11.04

11.89

10.82

11. 92
$\mathrm{Ca} / 10 \mu \mathrm{g}$ $\mathrm{mg} \% /$ Protein
Net

Change
$\%$

Change

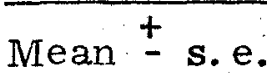

$2-$

1

2

3

9.97

8.25

9.76

8.63

10.87

9.98

Mean $\stackrel{t}{-}$ s.e.

3 -

1

12.04

11.30

$-0.87$

$-1.43$

11.8

$2 \quad 11.45$

11.22

$-0.27$

$-0.83$

7.2

$\begin{array}{lll}3 & 11.97 & 11.36\end{array}$

$-0.71$

11. 54

$-0.78$

11. 10

12. 11

12. 20

$-1.19$

$-1.26$

10.6

$-1.33$

11.0

$-1.74$

14. 5

Mean \pm s.e. 
Hypocalcemic Activity of Calcitonin Isolated from Ovine

Thyroid Slices Incubated in Krebs-Ringer Bicarbonate

Buffer Containg High Concentrations of Calcium.

Preparation Animal. No.
$\mathrm{Ca} \mathrm{mg} \%$ $t_{0}$

10.37

10.65

12.73

12.01

(10.1
$t_{50}$
$\mathrm{Ca} / 10 \mu \mathrm{g}$ $\mathrm{mg} \% /$ Protein
Net

Change
$\%$ Change

$$
1-
$$

$\begin{array}{ll}1 & 10.37 \\ 2 & 10.65 \\ 3 & 12.73 \\ 4 & 12.01\end{array}$

Mean \pm s.e.

9.97

$-0.35$

$-0.90$

8.8

(2)

9.74

$-0.82$

$-1.37$

12.0

Mean s.e.

$2-$

$1 \quad 11.12$

. 10.19

$-2.25$

$-2.80$

22.1

$-0.84$

$-1.39$

11.6

10.06

$2 \quad 11.06$

9.38

$-2.22$

$-1.61 \pm 0.41$

13. 6

$3 \quad 10.89$

9.61

$-1.22$

$-2.77$

25.0

Mean $t$ s.e.

8.86

$-1.72$

$-1.77$

16. 1

Mean s.e.

$$
3-
$$

$$
1
$$

11. 47

10. 54

$-1.10$

$-2.27$

20.9

$\frac{3-}{\text { Mean } \pm \text { s.e. }}$

$2 \quad 11.78$

10.74

$-1.22$

$-2.25 \pm 0.29$

20.7

3

12. 76

10.91

$-2.17$

$-1.65$

14.5

$4 \quad 11.52 \quad 10.24$

$-1.50$

$-1.77$

15.1

$5 \quad 12.38$

11.03

$-1.56$

$-2.72$

21.4

$-2.05$

17. $\dot{9}$

$-2.11$

17.9

Mean - s.e.

$$
-2.06 \pm 0.18
$$

17.2 
TABLE VII

The Effect of the Vehicle (0.1 M-Acetic Acid) for the

Calcitonin Preparations on the Serum Calcium of Rats

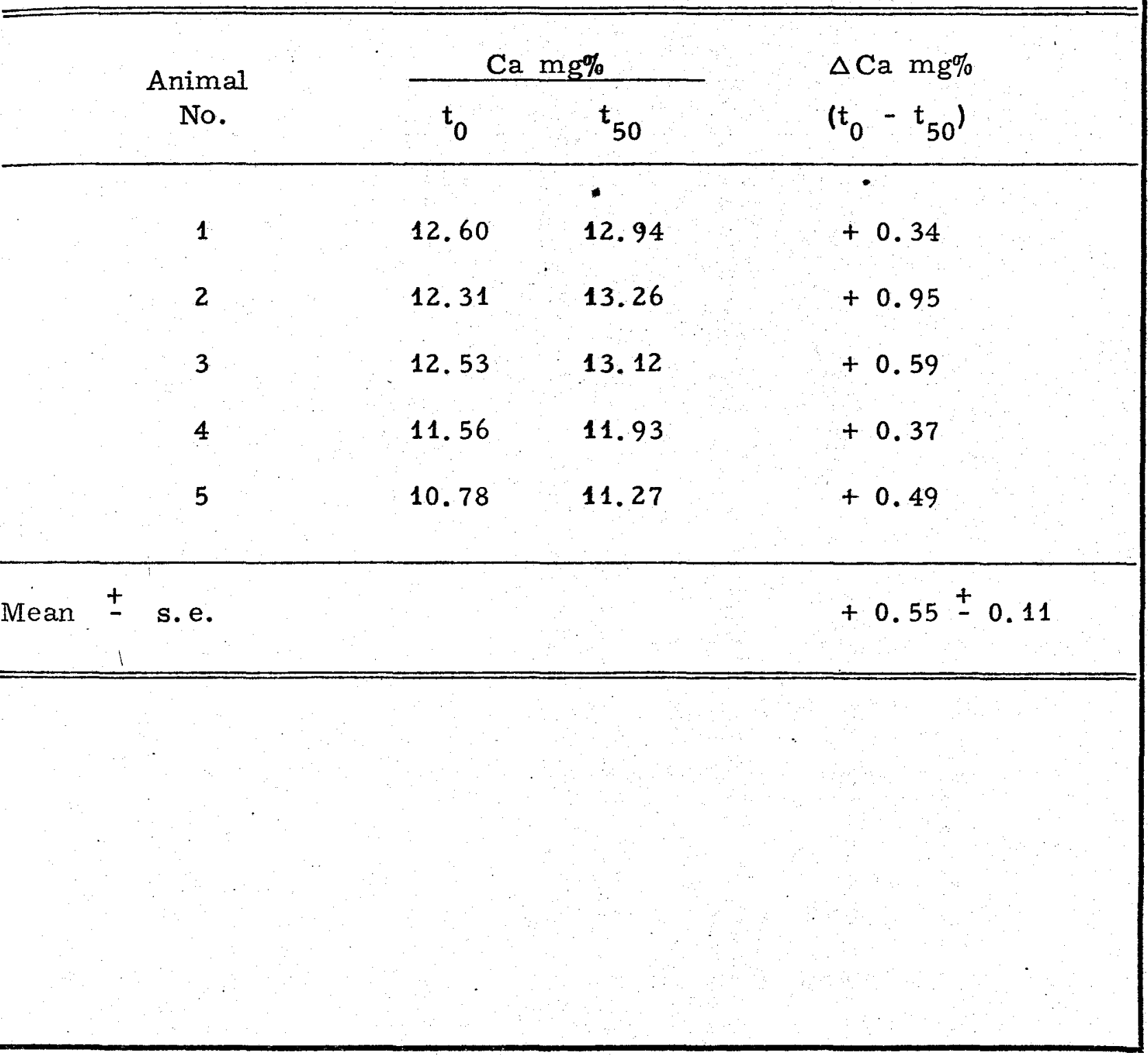


The Effect of High Magnesium Concentrations on the Synthesis of Calcitonin by Ovine Thyroid Slices.

This experiment was designed to determine whether the stimulation of calcitonin synthesis, observed when the glands were incubated in Krebs-Ringer bicarbonate buffer containing high concentrations of calcium, was due to a specific or a non-specific effect of calcium. For this purpose the Krebs-Ringer bicarbonate buffer was prepared such that the level of magnesium was increased eight times, and at the same time the sum of the magnesium and calcium ions was approximately equal to the sum of the calcium and magnesium ions in the KrebsRinger bicarbonate buffer containing high concentrations of calcium. Magnesium was chosen because its serum level is affected by parathyroid hormone the same as is calcium and in some cases it seems to be able to substitute for calcium; in fact, administration of magnesium is followed by an increased elimination of skeletal-bound radioactive calcium (Clark and Geoffray, 1958); furthermore, in vitro (Schachter and Rosen, 1959; Hendrix et al. 1963) and in vivo studies (Alcock and MacIntyre, 1962) suggest that magnesium and calcium act as competitors in intestinal absorption.

The procedures for incubations, isolation and assay of hypercalcemic activity were the same as those used for the demonstration of 
the effect of calcium. In both preparations (Tables VIII and IX) there is a small increase in hypocalcemic activity, but the difference of the means is not significant. Preparations incubated on the same day in Krebs-Ringer bicarbonate buffer containing physiological, and high concentrations of magnesium are compared in Table $X$. It is evident that magnesium has very little effect on the synthesis of calcitonin; the small increase in hypocalcemic activity may be due to the substitution of magnesium for calcium in processes not involved with calcitonin synthesis, thus freeing more calcium to exert its effect on the biosynthesis of calcitonin. The data is summarized in Table XI.

Effect of High Calcium Concentrations on the Release of Calcitonin from Ovine Thyroid Slices.

The in vivo studies do not distinguish whether the increase in circulating calcitonin is a result of increased synthesis, enhanced release or both. To determine whether calcium affected the release of calcitonin, two gram quantities of ovine thyroid slices were incubated in 50 ml Erlenmeyer flasks containing Krebs-Ringer bicarbonate buffer with either physiological or high concentrations of calcium. The incubations were carried on in an atmosphere of air at $37^{\circ} \mathrm{C}$ for 4 hours and were terminated by removing the tissue from the flasks. The medium from 


\section{TABLE VIII}

Hypocalcemic Activity of Calcitonin Preparations Isolated from Slices Incubated in Krebs-Ringer Bicarbonate Buffer Containing Physiological Concentrations of Magnesium.

\begin{tabular}{|c|c|c|c|c|c|c|}
\hline \multirow[t]{2}{*}{ Preparation } & \multirow{2}{*}{$\begin{array}{c}\text { Animal } \\
\text { No. }\end{array}$} & \multicolumn{2}{|c|}{$\mathrm{Ca} \mathrm{mg} \%$} & \multirow{2}{*}{$\begin{array}{l}\Delta \mathrm{Ca} / 10 \mu \mathrm{g} \\
\mathrm{mg} / \text { Protein }\end{array}$} & \multirow{2}{*}{$\begin{array}{c}\text { Net } \\
\text { Change }\end{array}$} & \multirow{2}{*}{$\begin{array}{c}\% \\
\text { Change }\end{array}$} \\
\hline & & $t_{0}$ & $t_{50}$ & & & \\
\hline \multirow[t]{3}{*}{1} & 1 & 10.75 & 10.44 & -0.41 & -0.96 & 9.0 \\
\hline & 2 & 10.94 & 10.61 & $=0.49$ & -1.04 & 9.6 \\
\hline & 3 & 11.10 & 9.95 & -1.65 & -2.21 & 19.9 \\
\hline \multicolumn{2}{|l|}{ Mean \pm s.e. } & & & -1.40 & \pm 0.42 & \\
\hline 2 & 1 & 12.04 & 11.30 & -0.87 & -1.42 & 11.8 \\
\hline & 2 & 11.45 & 11.22 & -0.27 & -0.82 & 7.2 \\
\hline & 3 & 11.97 & 11.36 & -0.71 & -1.26 & 10.6 \\
\hline & 4 & 12.20 & 11.54 & -0.78 & -1.33 & 11.0 \\
\hline & 5 & 12.11 & 11.10 & -1.19 & -1.74 & 14.5 \\
\hline
\end{tabular}




\section{TABLE IX}

Hypocalcemic Activity of Calcitonin Preparations Isolated from Ovine Thyroid Slices Incubated in Krebs-Ringer Bicarbonate Buffer Containing High Concentrations of Magnesium.

\begin{tabular}{|c|c|c|c|c|c|c|}
\hline \multirow[t]{2}{*}{ Preparation } & \multirow{2}{*}{$\begin{array}{c}\text { Animal } \\
\text { No. }\end{array}$} & \multicolumn{2}{|c|}{$\mathrm{Ca} \mathrm{mg} \%$} & \multirow{2}{*}{$\begin{array}{l}\Delta \mathrm{Ca} / 10 \mu \mathrm{g} \\
\mathrm{mg} / \text { /Protein }\end{array}$} & \multirow{2}{*}{$\begin{array}{l}\text { Net } \\
\text { Change }\end{array}$} & \multirow{2}{*}{$\begin{array}{c}\% \\
\text { Change }\end{array}$} \\
\hline & & $t_{0}$ & $t_{50}$ & & & \\
\hline \multirow[t]{3}{*}{$1-$} & 1 & 11.06 & 9.82 & -1.64 & -2.19 & -19.9 \\
\hline & 2 & 10.93 & 10.34 & -0.77 & -1.32 & -12.2 \\
\hline & 3 & 11. 13 & 10.15 & -1.31 & -1.86 & -16.8 \\
\hline
\end{tabular}

Mean $\stackrel{t}{\text { s.e. }}$

$-1.78 \pm 0.25$

$\begin{array}{rllllll}2- & 1 & 11.95 & 11.06 & -1.12 & -1.67 & -14.9 \\ 2 & 11.59 & 11.04 & -0.70 & -1.25 & -10.8 \\ 3 & 12.84 & 11.26 & -2.00 & -2.56 & -20.0 \\ 4 & 11.56 & 11.03 & -0.67 & -1.22 & -10.6 \\ 5 & 11.34 & 11.69 & -0.82 & -1.37 & -11.7\end{array}$

Mean \pm s.e.

$-1.61 \pm 0.24$ 
TABLE X

Hypocalcemic Activity of Calcitonin Preparations Isolated from Slices Incubated in Krebs-Ringer Bicarbonate Buffer Containing Physiological or High Concentrations of Calcium and Magnesium

Animal

No.
Net $\triangle \mathrm{Ca} \mathrm{mg} \%$

Physiological Hjgh Magnesium

$-1.78$

$-1.25$

$-2.57$

$-1.23$

$-1.38$
High Calcium
3

4

5
$-1.43$

$-0.83$

$-1.27$

$-1.34$

$-1.75$

$\therefore 1.3$

Mean \pm s.e. $-1.31 \pm 0.15$

$-1.62 \pm 0.25$

$-2.06 \pm 0.18$

$-1.66$

$-1.78$

$-2.73$

$-2.06$

$-2.12$

$P^{*}$

N.S.

$0.01-0.005$

*Probability of the significance of the difference determined by use of a Student's " $t$ " Test. 


\section{TABLE XI}

Summary of the Data on the Effect of Calcium

and Magnesium on the Synthesis of Calcitonin

$\frac{\text { Net } \Delta \mathrm{Ca} \mathrm{mg} \%(\mathrm{mean})}{10 \mu \mathrm{g} \text { Protein }}$

Normal

$\mathrm{High} \mathrm{Ca}^{++}$or $\mathrm{Mg}^{++}$

$\begin{array}{llllll}1-N & -1.02 \pm 0.18 & 1-H C & -1.61 \pm 0.41 & 0.1 \\ 2-N & -1.55 \pm 0.18 & 2-H C & -2.25 \pm 0.29 & 0.05 \\ 3-N & -1.31 \pm 0.15 & 3-H C & -2.06 \pm 0.18 & 0.01-0.005 \\ 1-N & -1.40 \pm 0.42 & 1-H M & -1.78 \pm 0.25 & \text { N.S. } \\ 2-N & -1.31 \pm 0.15 & 2-H M & -1.62 \pm 0.24 & \text { N.S. }\end{array}$

* Explanation of Symbols.

N - Preparations obtained from slices incubated in Krebs-Ringer bicarbonate buffer containing physiological concentrations of calcium and magnesium.

HC - Preparations obtained from slices incubated in buffer containing high concentrations of calcium.

HM - Preparations obtained from slices incubated in buffer containing high concentrations of magnesium.

Probability of the significance of the difference of the means as determined by the use of a Student's " $t$ " Test. 
each flask was assayed for hypocalcemic activity in two rats. Each rat received $150 \mu l$ of incubation medium. The control rats received $150 \mu 1$ of normal or high calcium Krebs-Ringer bicarbonate buffer. The results are presented in Tables XII, XIII and XIV.

The administration of normal buffer, which contained $676 \mu \mathrm{g}$ of calcium, increased the blood calcium by $5.7 \%$. The administration of the high calcium buffer, which contained $2.7 \mathrm{mg}$ of calcium increased the blood calcium by $4.5 \%$. The difference observed between the two groups is due to the response of the animal to the level of hypercalcemia induced by the administration of the two buffers. The high calcium buffer produced a higher original hypercalcemia than when the normal buffer was administered and consequently induced the production of larger amounts of calcitonin, which in turn decreased the blood calcium. Another factor was probably involved; the hypercalcemia depressed parathyroid function, which in turn decreased calcium mobilization from bone. The combined effects resulted in a lesser plasma calcium increase observed for those animals receiving higher doses of calcium.

The administration of the incubation medium containing physiological concentrations of calcium (Table XII) decreased the plasma calcium by $0.76 \mathrm{mg}$. However, since calcium was injected with the medium it 


\section{- $63-$ \\ TABLE XII}

Effect of Krebs-Ringer Bicarbonate Buffer Containing Physiological and High Concentrations of Calcium on the Plasma Calcium of Rats.

Physiological Buffer

Animal

No.

$\begin{array}{lll}1 & 11.20 & 11.03 \\ 2 & 11.06 & 11.69 \\ 3 & 10.71 & 11.64 \\ 4 & 10.56 & 11.43 \\ 5 & 10.51 & 11.35\end{array}$

Mean \pm s.e.

$\frac{\Delta \mathrm{Ca} m g \%}{\left(t_{50}-t_{0}\right)}$

$-0.17$

$+0.63$

$+0.93$

$+0.87$

$+0.84$

High Calcium Buffer

Animal

No.
Ca $\mathrm{mg} \%$

$t_{50}$

$+0.62 \pm 0.12$ 
Serum Calcium Changes Induced by the Administration of Incubation Media Containing Physiological Concentrations of Calcium.

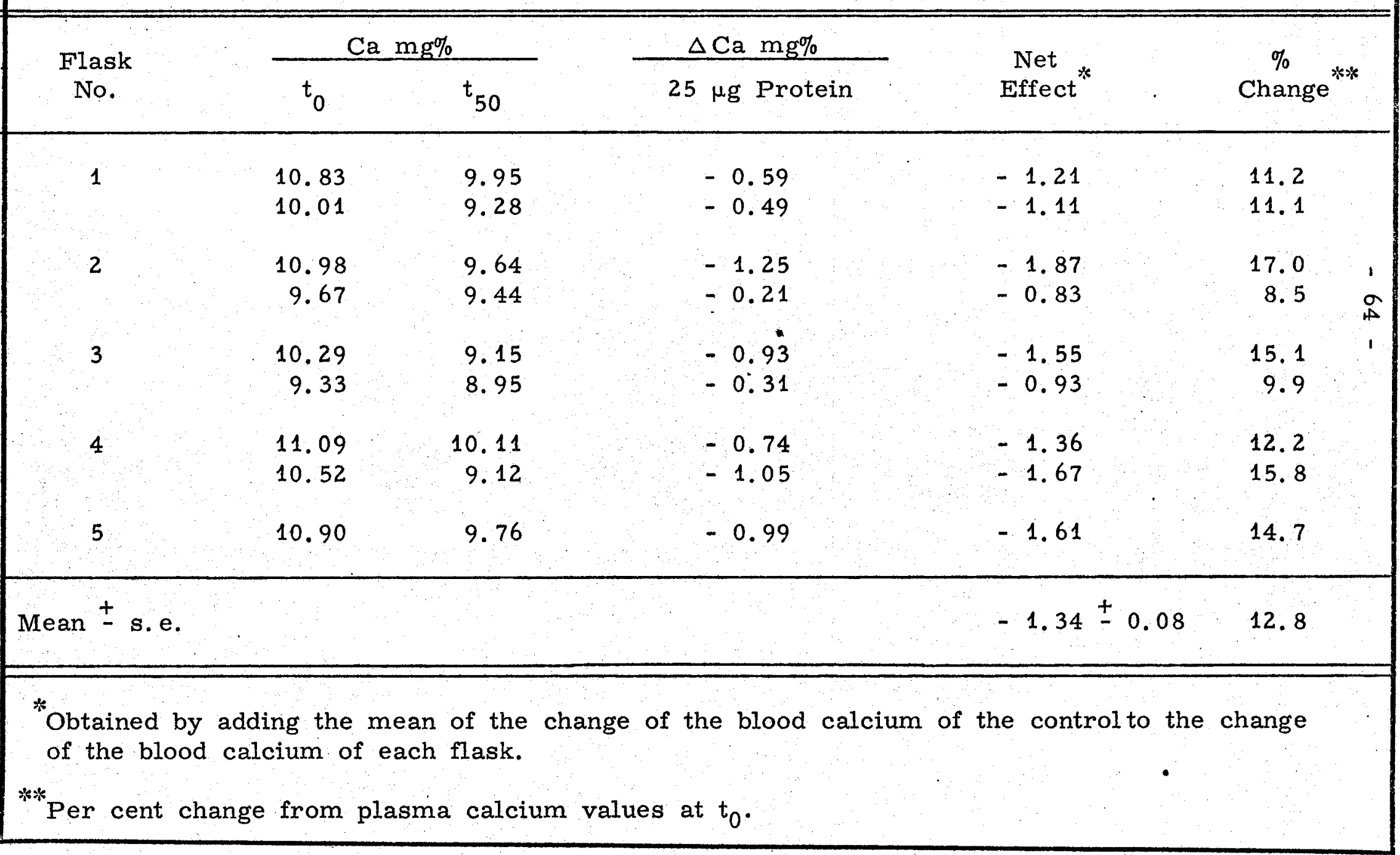


TABLE XIV

Serum Calcium Changes Induced by the Administration of Incubation Media Containing High Concentrations of Calcium.

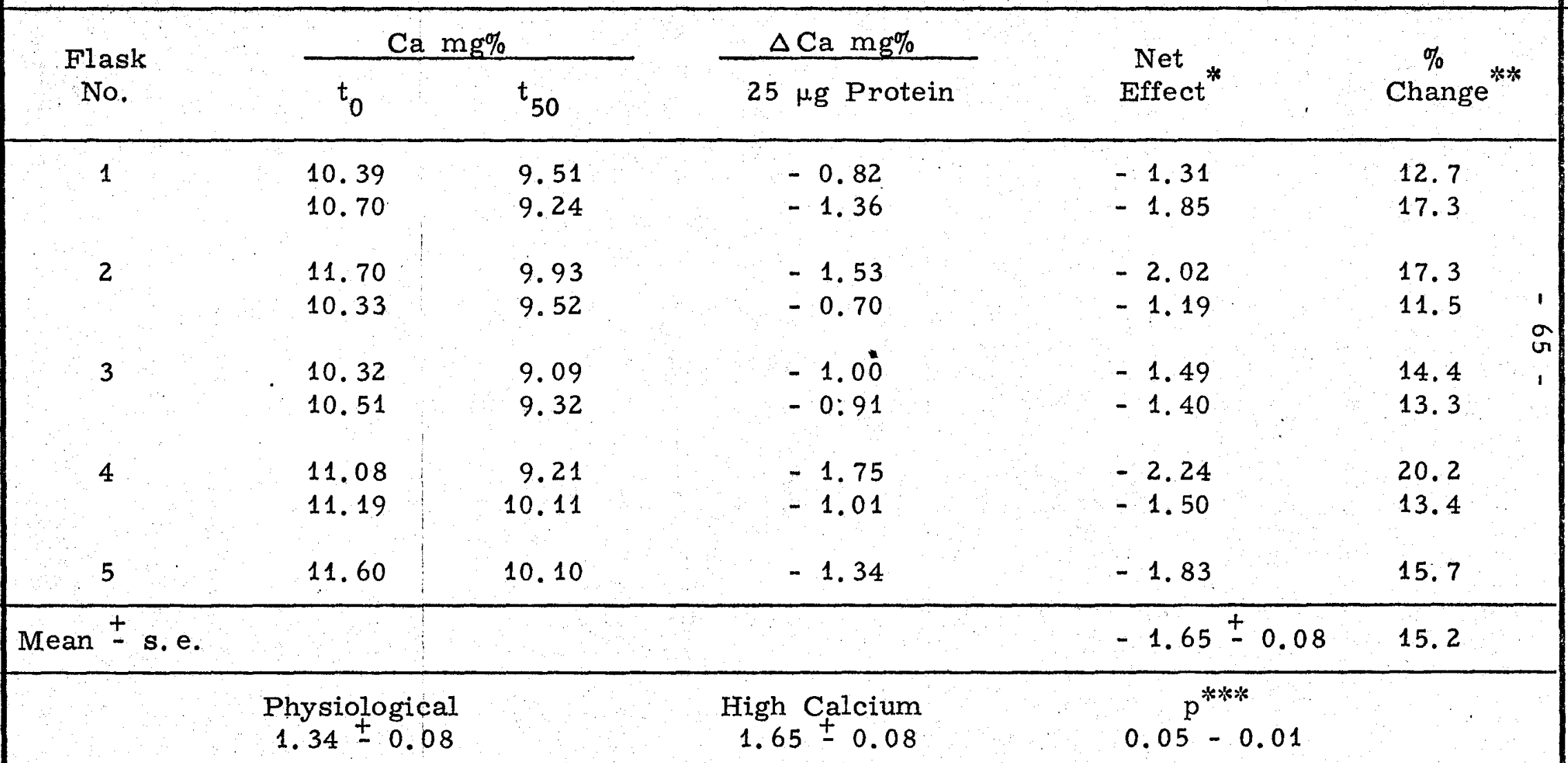

*Obtained by adding the mean of the change of the blood calcium of the control (Table VI) to the change of the blood calcium for each flask.

**Per cent change from plasma calcium values at $t_{0}$.

***:Probability of the significance of the difference determined by the use of a Student's " $t$ " statistic. 
should be taken into account. By adding the change brought about by the vehicle (Table XII) we obtained the net change in plasma calcium, $1.45 \mathrm{mg}$ or $13.6 \%$. The administration of the incubation media containing high calcium concentrations (Table XIV) decreased the serum calcium by $1.17 \mathrm{mg}$. The net change is $1.68 \mathrm{mg}$ or $15.4 \%$. When the net change obtained by administering normal and high calcium incubation media are compared, we find that the difference of the means is statistically significant, indicating that the release of calcitonin is under the direct influence of calcium.

Isolation and Purification of Calcitonin

To determine whether the hypocalcemic activity that was observed was due to calcitonin and not to some other unknown factor, calcitonin was isolated and purified. 200 grams of fresh glands were incubated in $50 \mathrm{ml}$ Erlenmeyer flasks. Each flask contained 2.0 grams of thyroid slices, $10 \mathrm{ml}$ of Krebs-Ringer bicarbonate buffer containing high concentrations of calcium and $2.5 \mu \mathrm{Ci}$ of glycine-C-14 (UL). The incubations were carried on in an atmosphere of air at $37^{\circ} \mathrm{C}$ for four hours. After the incubations were terminated with trichloroacetic acid, the slices were minced and defatted. The defatted material was extracted with urea-cysteine-HCl. The extract was dialyzed against $0.1 \mathrm{M}$ acetate 
buffer for 24 hours at $4^{\circ} \mathrm{C}$. The dialyzate was made $1.0 \underline{\mathrm{M}}$ with 3.0 M $\mathrm{NaCl}$ and allowed to stand 72 hours at $4^{\circ} \mathrm{C}$. The inactive precipitated protein was collected by centrifugation and discarded. To the supernatant was added solid $\mathrm{NaCl}$ to make a $2.0 \mathrm{M}$ solution and allowed to stand 72 hours at $4^{\circ} \mathrm{C}$. The active precipitate was collected by centrifugation and lyophilized.

The lyophilized material weighed $120 \mathrm{mg}$. It was dissolved as completely as possible in $6.5 \mathrm{ml}$ of $0.1 \mathrm{M}$ formic acid and the mixture centrifuged to remove suspended material. $4 \mathrm{ml}$ of the supernatant was applied to a $40 \times 2.5 \mathrm{~cm}$ column of Sephadex G-100 and eluted with 0.1 M formic acid. Figure 5 shows the elution pattern, the radioactivity and the protein content of each fraction as measured by the Lowry method (1956). The first $60 \mathrm{ml}$, the void volume, were discarded. The absorption at $280 \mathrm{~m} \mu$ gave only one well-defined peak; however, when each fraction was analyzed for protein content by the Lowry method three protein peaks became evident. The hypocalcemic activity was confined entirely to the second protein peak. Radioactivity was high in the fractions containing hypocalcemic activity with $18,000 \mathrm{DPM} /$ $\mathrm{mg}$ protein in fraction 6 and falling to $8,000 \mathrm{DPM} / \mathrm{mg}$ protein in fraction 10.

The fractions containing hypocalcemic activity were lyophilized 


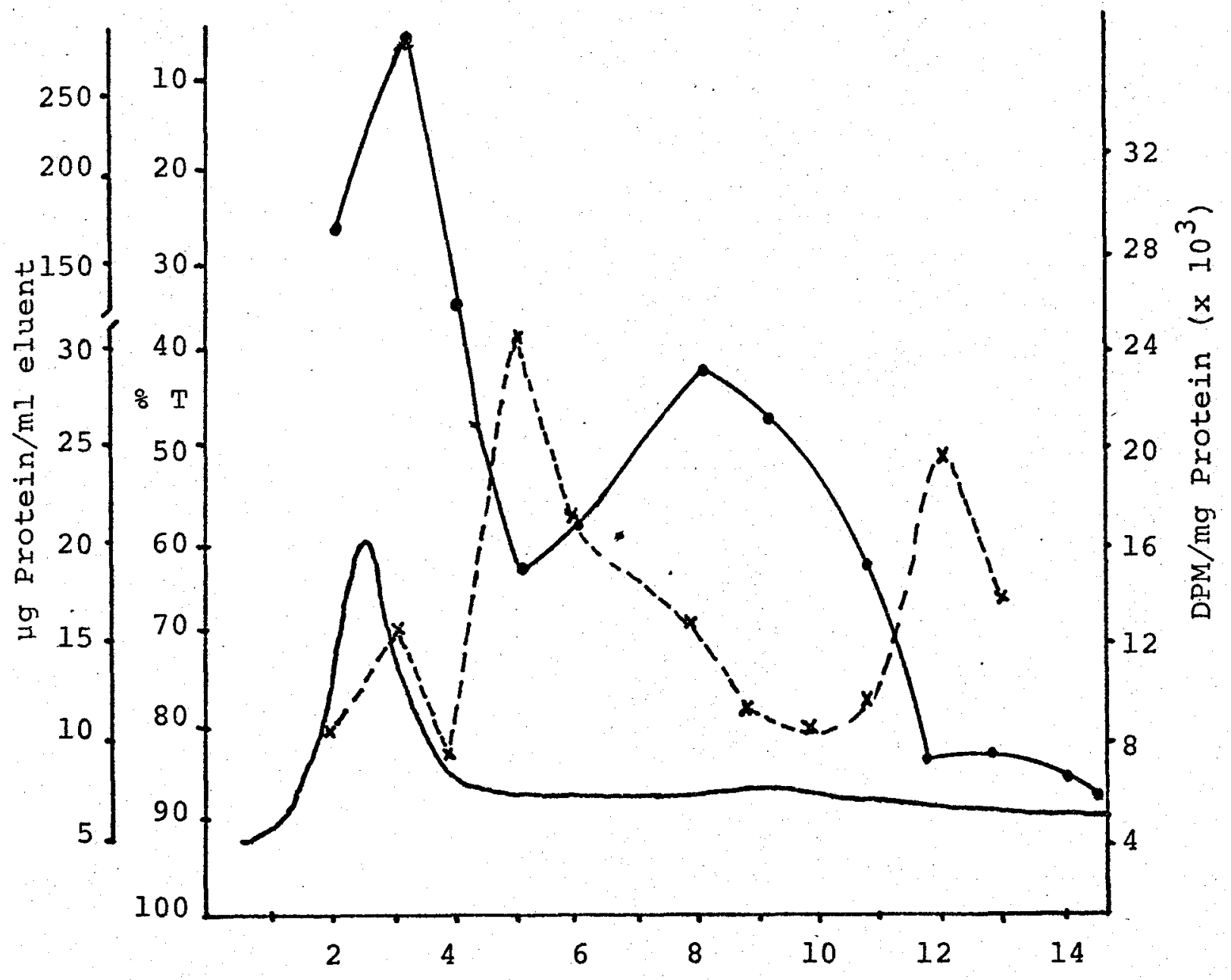

Fraction No.

FIGURE 5. Protein content $(\bullet-\bullet)$, radioactivity $(x-\cdots-x)$ and elution pattern ( - ) of $\mathrm{NaCl}$ precipitated calcitonin preparation on a column of Sephadex G-100. Flow rate: $.34 .5 \mathrm{ml}$ per hour; $4.0 \mathrm{ml}$ fractions collected. Hypocalcemic activity indicated by horizontal bar $(\longmapsto)$ 
and $1.3 \mathrm{mg}$ of solid material was obtained. $600 \mu \mathrm{g}$ of this material, containing $456 \mu \mathrm{g}$ of protein, were dissolved in $0.1 \underline{\mathrm{M}}$ acetic acid and used for the assay of hypocalcemic activity. This solution was diluted 1:50 with $0.1 \mathrm{M}$ acetic acid and $250 \mu \mathrm{l}$ of the diluted solution, containing $0.56 \mu \mathrm{g}$ protein, was injected into each rat. The hypocalcemic activity of this material is shown in Table XV. The average change in serum calcium is $-0.82 \mathrm{mg}$. When we add the change resulting from the vehicle alone, which is $+0.56 \mathrm{mg}$ we obtain a net effect of $-1.38 \mathrm{mg}$ or an $11 \%$ drop in serum calcium. From the definition of a unit, 0.56 $\mu \mathrm{g}$ of protein is equivalent to 11 milliunits and $1.0 \mathrm{mg}$ of protein is equivalent to $19.5 \mathrm{MRC}$ units.

$700 \mu \mathrm{g}$ of the material obtained by lyophilizing the fractions from Sephadex G-100 containing hypocalcemic activity were dissolved in 350 $\mu \mathrm{l}$ of $1.0 \mathrm{M}$ formic acid and applied to a $45 \times 0.9 \mathrm{~cm}$ column of Sephadex G-50 superfine; it was then eluted with 0.1 M formic acid 1.0 M urea $-0.2 \mathrm{M} \mathrm{NaCl}$. The elution pattern is shown in Figure 6 . The hypocalcemic activity is confined to the main protein peak; radioactivity was associated mainly with the fractions containing the hypocalcemic activity. The active fractions were pooled and lyophilized. The lyophilized material was dissolved in $0.1 \mathrm{M}$ acetic acid containing $0.1 \%$ albumin and assayed for hypocalcemic activity. The albumin was 
TABLE XV

Hypocalcemic Activity of Lyophilized Fractions

from the Sephadex G-100 Column.

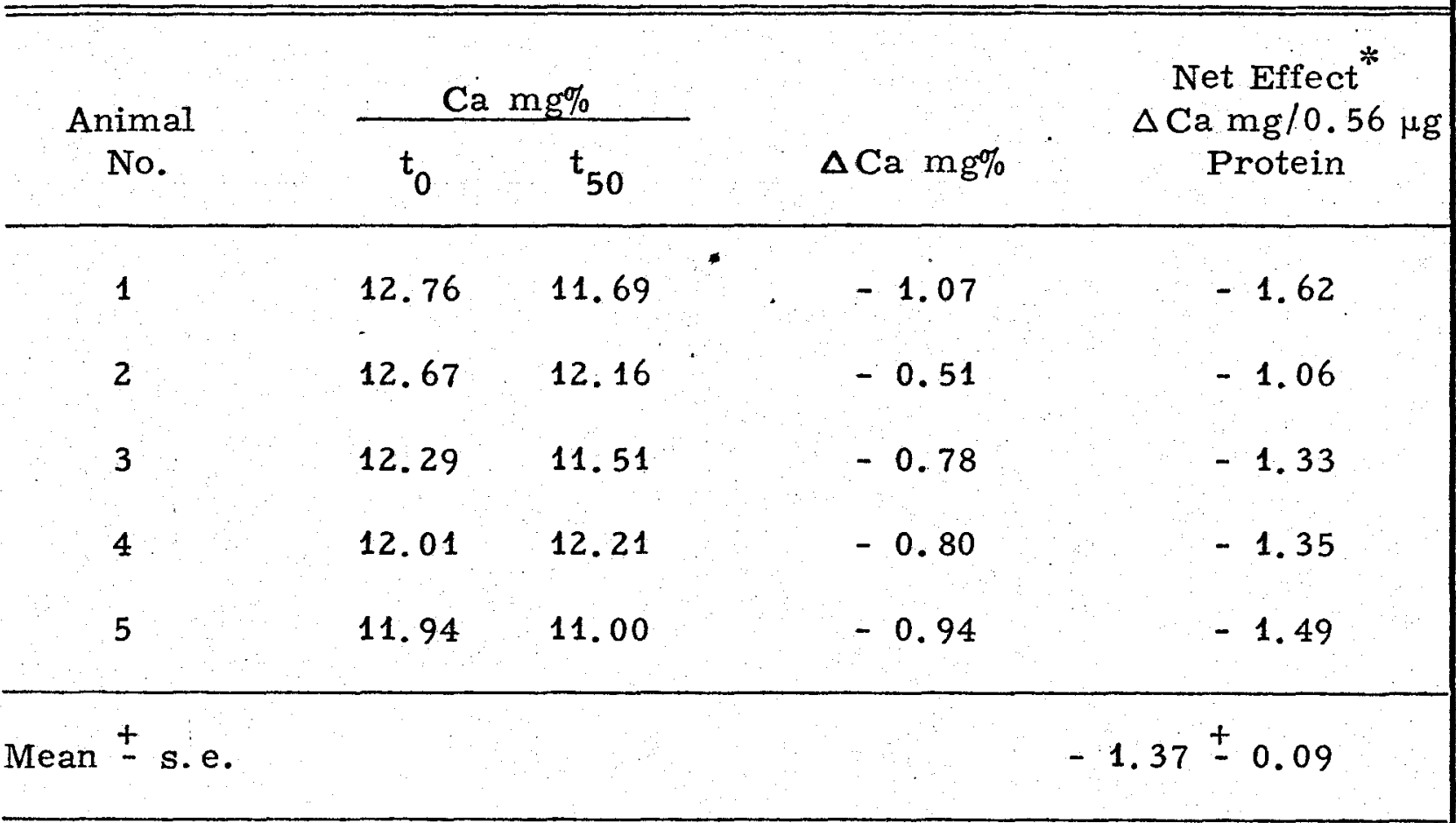

* Obtained by adding the mean of the change of the serum calcium of the controls (Table VII) to the change of the serum calcium of each animal that received the experimental preparation. 


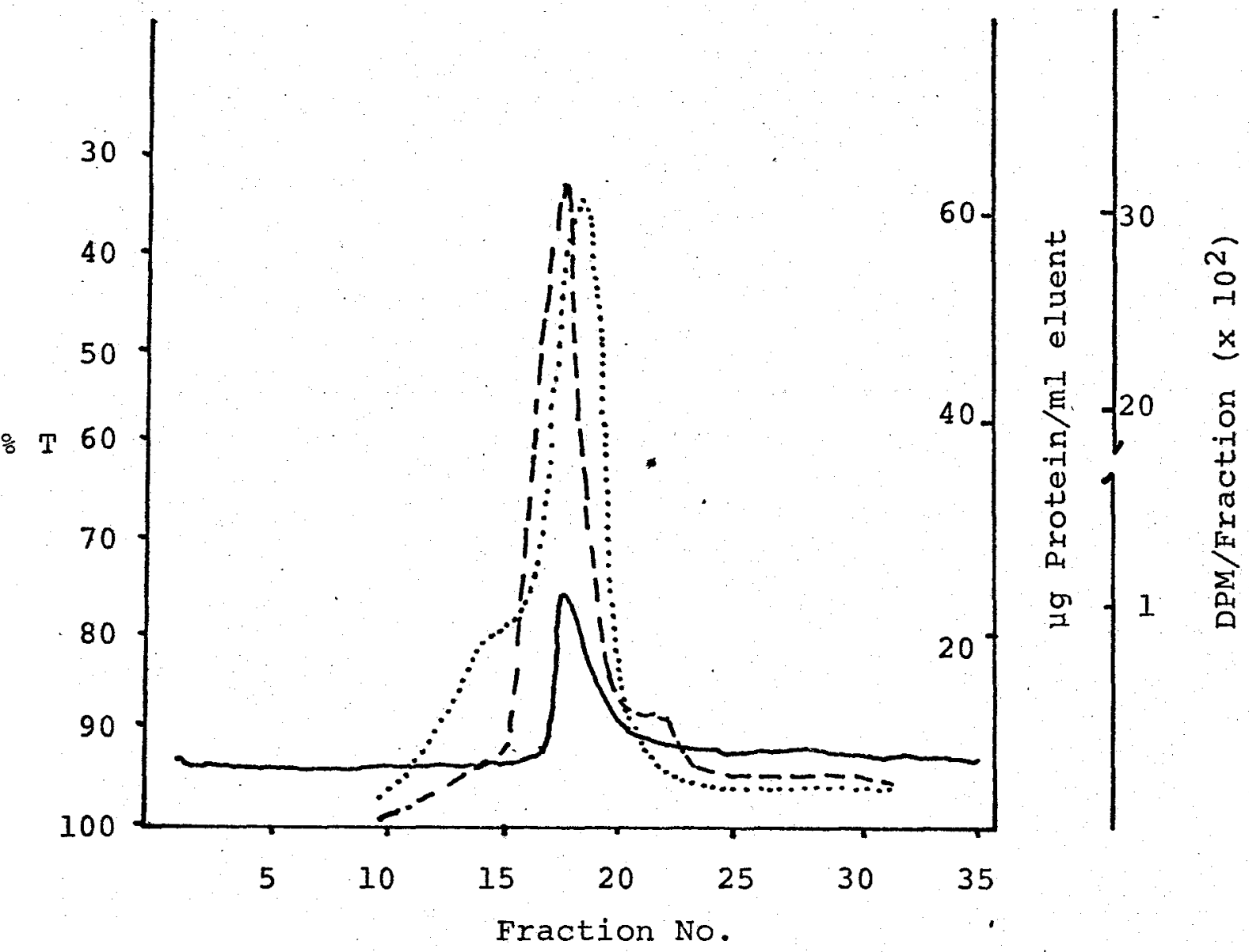

FIGURE 6. Elution pattern of hypocalcemic activity from a Sephadex G-50 superfine column. Flow rate: $6 \mathrm{ml}$ per hour; $1.0 \mathrm{ml}$ fractions were collected. The hypocalcemic activity was eluted as a single peak at fractions 16, 17 and 18. expansion of the \% $\mathrm{T}$ scale. Protein content ( $0-\cdots-0)$. Radioactivity $(\ldots \ldots)$ 
added to counteract the tendency of calcitonin to become adsorbed to glass surface of the container (Parsons, 1967). 140-170 gram rats were injected with $200 \mu l$ of the calcitonin, solution into the femoral vein. The control animals received $200 \mu \mathrm{l}$ of the lyophilized eluent used to elute calcitonin from the Sephadex G-50 column. The lyophilized eluent was dissolved in $0.1 \underline{\mathrm{M}}$ acetic acid and administered to the animals. The hypocalcemic activity is shown in Table XVI. Since $0.18 \mu \mathrm{g}$ of protein produces an $11.7 \%$ fall in calcium, it can be calculated that the potency of the purified calcitonin is $66.5 \mathrm{MRC}$ units per milligram protein.

Characterization of the Purified Calcitonin

To assess the purity of the calcitonin obtained the individual fractions (16, 17 and 18) containing hypocalcemic activity were chromatographed on a thin layer Eastman Chromatogram Sheet 6065 (cellulose with fluorescent indicator) and developed with the upper phase of a butanol: acetic acid: water $(4: 1: 5)$ system for 2.5 hours. The protein spots under short ultraviolet light $(254 \mathrm{~m} \mu)$ are visible as dark purple spots on a yellow fluorescent background. Only one spot for each fraction was visible (Figure 7), and it appears that the protein in each fraction is homogenous. Since the spots of all three fractions had the 
TABLE XVI

Hypocalcemic Activity of Lyophilized Fractions from Sephadex G-50 Superfine

\begin{tabular}{|c|c|c|c|c|c|c|c|c|}
\hline \multirow{2}{*}{$\begin{array}{c}\text { Animal } \\
\text { No. }\end{array}$} & \multicolumn{2}{|c|}{$\mathrm{Ca}^{++} \mathrm{mg} \%\left(t_{0}\right)$} & \multicolumn{2}{|c|}{$\mathrm{Ca}^{++} \mathrm{mg} \%\left(t_{50}\right)$} & \multicolumn{2}{|c|}{$\triangle \mathrm{Ca} \quad \mathrm{mg} \%$} & \multirow{2}{*}{$\begin{array}{l}\text { Net Effect* } \\
\text { per } 0.18 \mu \mathrm{g} \\
\text { Protein }\end{array}$} & \multirow[b]{2}{*}{$\%$ Change } \\
\hline & Control & Exper. & Control & Exper. & Control & Exper. & & \\
\hline 1 & 10.86 & 10.93 & 11.16 & 10.13 & +0.42 & -0.80 & -1.26 & 11.5 \\
\hline 2 & 10.57 & 10.55 & 11.26 & 9.93 & +0.69 & -0.62 & -1.39 & 13.1 \\
\hline 3 & 10.94 & 10.77 & 11.52 & 10.20 & +0.58 & -0.57 & -1.21 & 11.1 \\
\hline 4 & 10.76 & 10.85 & 11.18 & 10.09 & +0.30 & -0.76 & -1.16 & 10.4 \\
\hline 5 & 10.66 & 11.52 & 11.64 & 10.85 & +0.98 & -0.67 & -1.35 & 12.5 \\
\hline \multicolumn{3}{|c|}{ Mean - s.e. } & & & +0.59 & -0.68 & -1.27 & 11.7 \\
\hline \multicolumn{9}{|c|}{$\begin{array}{l}\text { * Obtained by adding the mean of the change of the blood of the calcium of the control animals } \\
\text { to the change of the blood calcium of each experimental animal. }\end{array}$} \\
\hline
\end{tabular}


Solvent Front

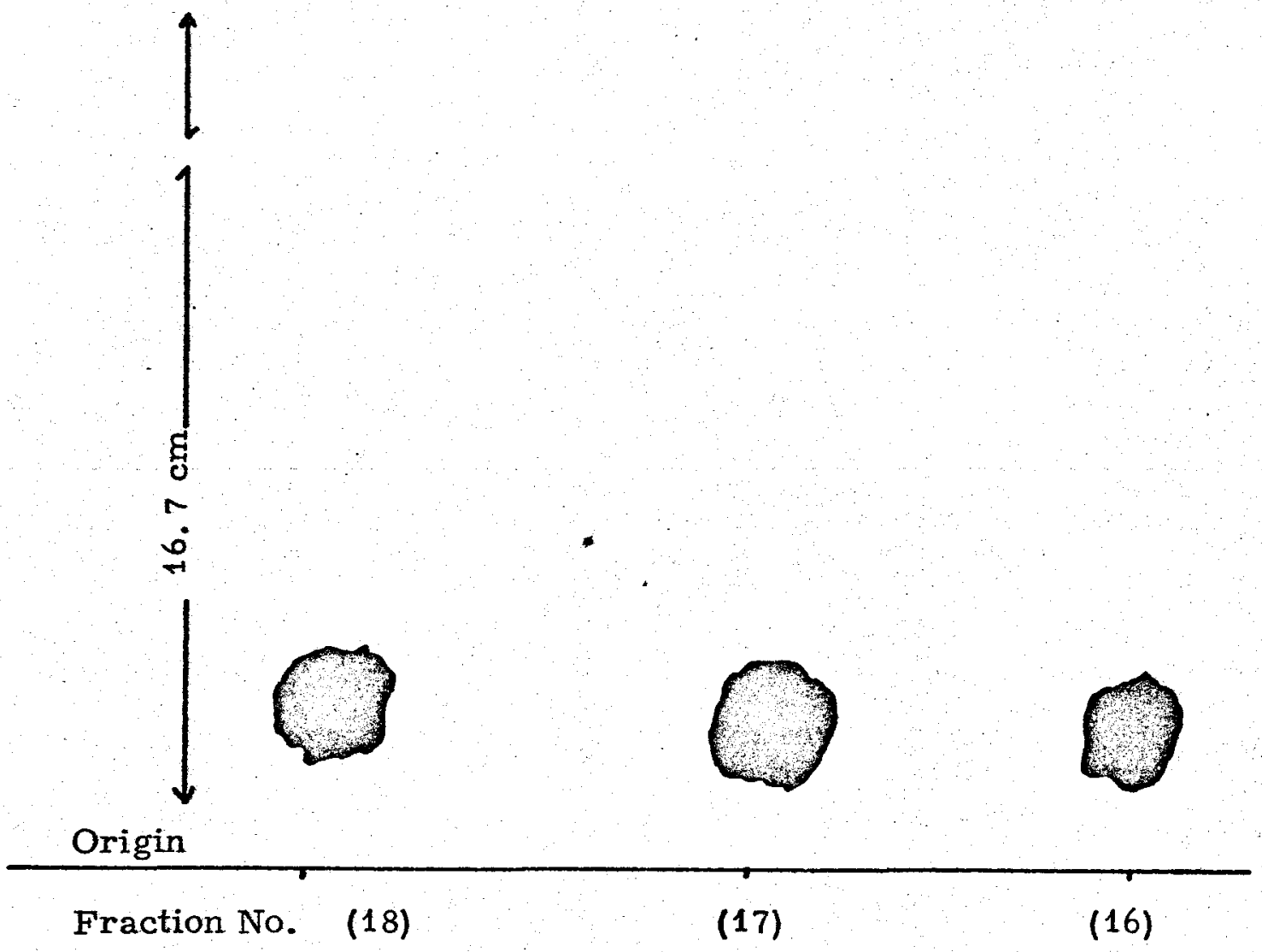

FIGURE 7. Reproduction of thin layer chromatogram of fractions containing hypocalcemic activity eluted from Sephadex G-50 superfine. The chromatogram, on Eastman cellulose sheet with fluorescein indicator was developed in a butanol: acetic acid: water $(4: 1: 5)$ system for 2.5 hours. 


\section{$-75-$}

same $R_{f}$ value $(0.116)$ the protein in all three fractions is presumably the same.

An aliquot of the combined fractions was subjected to two-dimensional chromatography. The chromatogram was developed in one direction with the upper phase of a butanol: acetic acid: water system and in the other direction with a propanol: water $(70: 30)$ system. Since only one spot was visible on the two-dimensional chromatogram (Figure 8), it appears that the preparation was homogenous.

To determine with certainty whether the protein was calcitonin or not and whether it was contaminated by other protein material $3.0 \mu \mathrm{g}$ protein was hydrolyzed for 24 hours at $110^{\circ} \mathrm{C}$ in $6.0 \mathrm{~N} \mathrm{HCl}$. The hydrolysate was evaporated to dryness in a flash evaporator, and twice redissolved in water and dried again. After the last drying it was dissolved in $600 \mu \mathrm{l}$ of $0.01 \mathrm{~N} \mathrm{HCl}$ and analyzed for amino acids on a TSM Amino Acid Autoanalyzer. Figure 9 shows the pattern of eluted amino acids. The absence of lysine and isoleucine are strong indications that the peptide is calcitonin. The glycine peak was collected and evaporated, almost to dryness, and diluted to $10 \mathrm{ml}$ with water. A 100 $\mu l$ aliquot was measured for radioactivity and found to contain radioactivity. 
(1)

(2)

Origin

FIGURE 8. Reproduction of two-dimensional chromatogram of lyophilized hypocalcemic active fractions eluted from Sephadex G-50 superfine. The chromatogram on Eastman cellulose sheet was developed in direction 1 with a butanol: acetic acid: water $(4: 1: 5)$ system and in direction 2 with a propanol: water $(70: 30)$ system. 


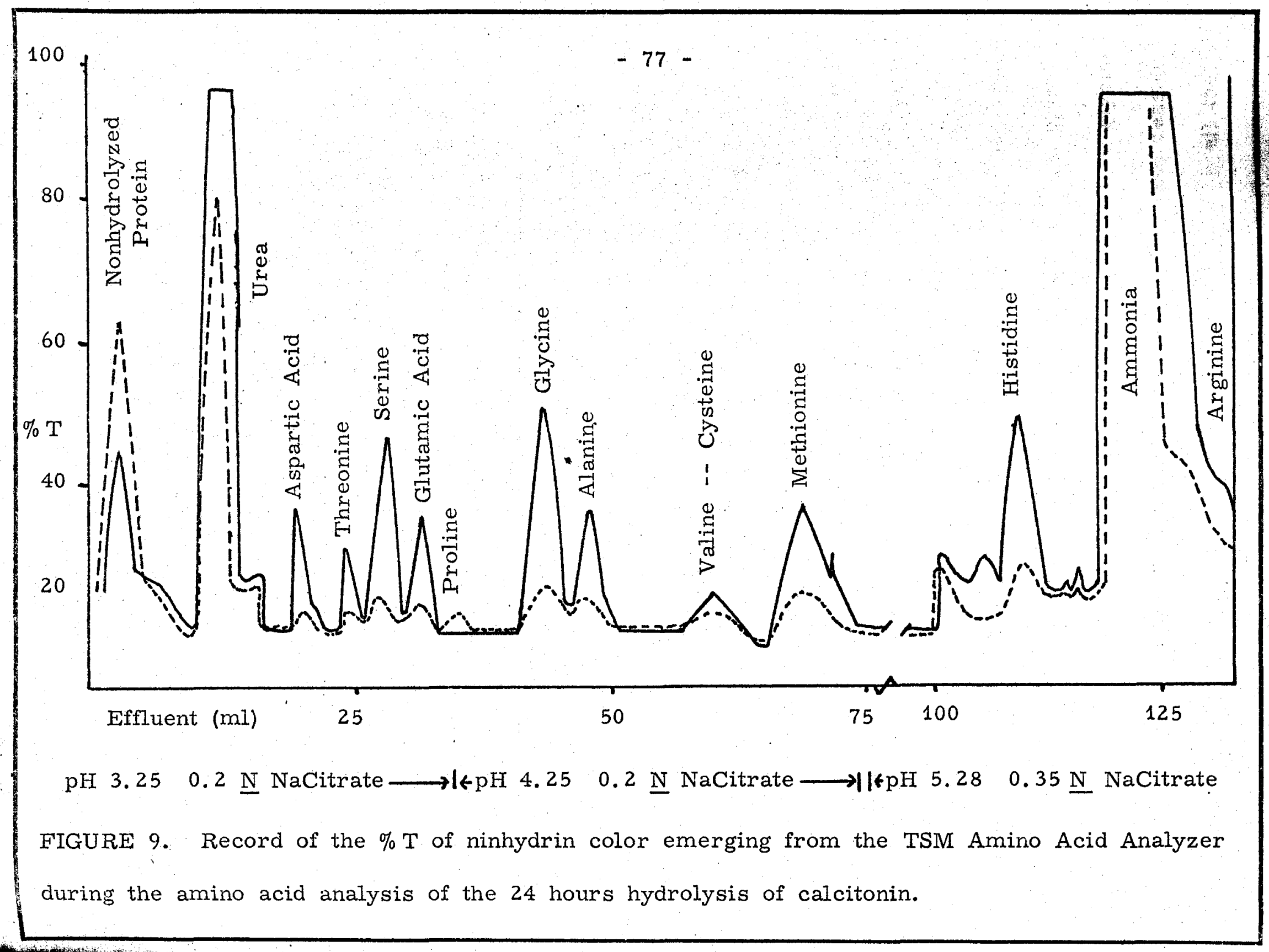




\section{CHAPTER IV}

\section{DISCUSSION}

From information provided by previously reported studies on the in vitro biosynthesis of several polypeptide hormones (Adiga et al. 1965; Bauer and Lazarow, 1961; Mallory et al. 1964; Sacks, 1963; Steiner and Oyer, 1967) it appeared likely that the biosynthesis of calcitonin could be demonstrated in vitro. To our knowledge, no attempts have been made to demonstrate the synthesis of calcitonin.

In this study the composition of the incubation medium necessary to give high incorporation of glycine-C-14 into the protein fraction of the thyroid tissue was defined. It was found that the addition of glucose $(320 \mathrm{mg} / 100 \mathrm{ml})$ to Krebs-Ringer bicarbonate buffer (pH 7.4) increased incorporation markedly (200\%). Glucose acts as the energy source for biosynthesis. The addition of the 15 amino acids of calcitonin to the Krebs-Ringer buffer had very little effect on the incorporation of label in proteins. In this instance, as was the case when no additions were made, the lack of an energy source would limit biosynthesis and, thus, the observed glycine-C-14 incorporation. The addition of both glucose and the 15 amino acids of calcitonin increased incorporation of glycineC-14 by $100 \%$, less than when glucose alone was added. The reason for this inhibitory effect of the amino acids is not clear. In all the 
incubations the buffer which contained both glucose and amino acids was used. The inhibitory effect of the amino acids is possibly due to the suppression of synthesis of thyroid proteins in favor of the synthesis of those peptides that contain only the exogenously added amino acids : for the de novo synthesis of proteins would have to come from the limited pool of free amino acids already existing in the tissue slices, from breakdown of proteins and from gluconeogenesis, with the result that many peptides and proteins would be synthesized. When exogenous amino acids were added the system would use these preferentially resulting in the preferential synthesis of those proteins and peptides made up of the exogenous amino acids, and since calcitonin is one of these peptides its synthesis would be preferentially stimulated.

To demonstrate the synthesis of calcitonin, ovine thyroid glands were incubated in Krebs-Ringer bicarbonate buffer for 4 hours at $37^{\circ} \mathrm{C}$. After incubation the slices were defatted and extracted with 10 volumes of $8.0 \mathrm{M}$ urea $-0.1 \underline{\mathrm{M}}$ cysteine in $0.2 \mathrm{~N} \mathrm{HCl}$. The urea-cysteine-HCl system has been used with success in the extraction of calcitonin by Potts et al. (1967). For the isolation of calcitonin from the extract, the method of Gudmundsson et al. (1966) was used. Calcitonin was isolated through the second sodium chloride precipitation step. The precipitate was lyophilized, dissolved in $0.1 \mathrm{M}$ acetic acid and administered intra- 
venously to $140-170$ gram rats. When the hypocalcemic activity of incubated and non-incubated glands was compared, no difference was observed. Since calcitonin titers in the circulation seem to be controlled by the blood calcium concentrations, the calcium concentration in the media was increased in an attempt to stimulate calcitonin synthesis. A four-fold increase in calcium markedly stimulates calcitonin synthesis. In vivo studies by Gittes et al. (1968) have shown that the extractable content of calcitonin in the thyroid gland is markedly reduced after hypercalcemic stimulation. Care et al. (1968), on the other hand, observed no difference in the calcitonin content of the thyroids from pigs subjected to hypercalcemia and from normal pigs. Our results are in disagreement with the findings of Gittes and Care. The reason for the conflicting results is due to the different methods used. Both Gittes and Care made their measurements in vivo, where measurements of the calcitonin content of the thyroid glands are complicated by the fact that during the time of perfusion with high calcium synthesis may occur, but it may be masked by the continuous secretion and destruction of the hormone at the target organ.

In an effort to determine whether the stimulation of calcitonin synthesis was a specific effect of calcium or whether magnesium could substitute for calcium, the concentration of magnesium was increased in 
such a way that the ionic strength of the high calcium and high magnesium media were the same. Magnesium was chosen because about $60 \%$ of the total body magnesium is located on the surface of bone, incapable of penetration into the lattice interior. It exchanges for calcium in bone on a mole-for-mole basis (Blaxter, 1956). It has also been shown that the levels of serum and urinary magnesium are controlled by parathyroid hor mone in a manner similar to that of calcium (Bethune et al. 1968). The results of this study show that magnesium did not significantly affect the synthesis of calcitonin, therefore, the mechanism by which calcium stimulates the synthesis of calcitonin is not affected by magnesium. The molecular basis for the calcium activation of the synthesis of this particular peptide is completely unknown. It may increase the uptake of amino acids by the cells; in the parathyroid it has been shown to decrease the uptake of the amino acid analog a-aminoisobutyric acid (Raisz and O'Brien, 1963). Further studies would be needed to establish how calcium brings about its effect.

When calcitonin is injected into rats it produces hypocalcemia which starts a few minutes after administration of the hormone and reaches a maximum at about one hour and returns to normal within three hours (Kumar et al. 1965; Hirsch et al. 1964). It has been demonstrated both in vivo (Milhaud et al. 1965b;. Martin et al. 1966) and 
in vitro (Friedman and Raisz, 1965; Aliapoulios et al. 1966) that calcitonin produces its hypocalcemic response by inhibiting bone resorption. MacIntyre (1967) has shown that the hormone is biologically active on isolated, perfused cat tibia proving that the effect is a direct one. The mechanism that controls the titer of the circulating hormone seems to be similar to that controlling parathyroid hormone. Secretion of parathyroid hormone has been shown to be controlled by blood calcium concentration; hypocalcemia enhancing secretion and hypercalcemia abolishing secretion (Sherwood et al. 1968). Calcitonin has also been shown to be dependent upon blood calcium. Work bý Care et al. (1967) indicated that the secretion of calcitonin was controlled by a negative feedback which operated through the blood calcium concentration. Care et al. (1968) measured the secretion of calcitonin in pigs in vivo and were able to demonstrate that there was a linear relationship between calcitonin in the venous blood and the concentration of calcium in the perfusing medium over a range of calcium of 6-10 meq/liter. Below 6 meq/liter of calcium they were not able to detect calcitonin. Lee et al. (1969) have shown that calcitonin is secreted at normal blood calcium concentrations and even below. The manner by which calcium controls the secretion rate of calcitonin is unclear. It could act directly on the secretion granules of the C cells or its action may be mediated by an un- 
known messenger. Gittes and Irvin (1965) suggested that a parathyroid factor may have been responsible for release of calcitonin; subsequent studies, however, failed to confirm their hypothesis (Foster, 1968; Toverud et al. 1966). Control of calcitonin secretion by the pituitary gland has been investigated and there is no evidence of such a control (Milhaud and Mauktar, 1965). Recently Avioli et al. (1968) have found that calcitonin is released by glucagon. The results obtained in this investigation support the hypothesis that calcium exerts a direct effect on the release of calcitonin from the thyroid gland; in fact, an increase in the concentration of calcium in the incubation media led to an increase in the release of the hormone. From the data obtained, it can be calculated that the glands incubated in Krebs-Ringer buffer containing a high calcium concentration, 500 MRC milliunits, of calcitonin were released per gram of glands per 4 hours. The glands incubated in buffer containing physiological concentrations of calcium released 442 MRC milliunits calcitonin per gram per 4 hours.

Since the hypocalcemic effect observed upon administration of the calcitonin preparations may have been the result of some unknown impurity, the hormone was purified. For purification the method of Gudmundsson et al. (1966) was used. The lyophilized material, obtained by precipitation in $2.0 \mathrm{M} \mathrm{NaCl}$, was dissolved in $0.1 \mathrm{M}$ formic acid 
and applied to a Sephadex G-100 column. The fractions containing hypocalcemic activity were combined and lyophilized. The lyophilized material was found to have very high biological activity; $0.56 \mu$ protein lowered the serum calcium of rats by $11 \%$ which corresponds to 11 MRC milliunits activity by definition; it can be calculated that the activity of this fraction was $19.5 \mathrm{MRC}$ units per $\mathrm{mg}$ protein. $700 \mu \mathrm{g}$ of the lyophilizate was dissolved in $0.35 \mathrm{ml}$ of $1.0 \mathrm{M}$ formic acid and applied to a $45 \times 0.9 \mathrm{~mm}$ column of Sephadex G-50 superfine. The hypocalcemic activity was found in fractions 16, 17 and 18. These three fractions comprised the main protein peak. These fractions were combined and lyophilized and the hypocalcemic activity assayed. It was found that $0.18 \mu \mathrm{g}$ of protein decreased the serum calcium of rats by $12 \%$, which is equivalent to $12 \mathrm{MRC}$ milliunits activity or $66.7 \mathrm{MRC}$ units per milligram protein. The activity of chemically synthesized calcitonin is much higher, about 200 MRC per milligram. The lower activity of our preparation is possibly due to denaturation which occurred during isolation and purification, or to species differences. The protein in all three fractions was homogenous on thin layer chromatography and the $R_{f}$ value was the same, indicating that the protein was identical in the three fractions. An aliquot of the pooled fractions was found to be homogenous on two-dimensional thin layer 
chromatography. Amino acid analysis of an aliquot of the combined fractions was found to lack both lysine and isoleucine and since porcine calcitonin lacks these two amino acids, it is further proof that calcitonin was actually isolated and purified, and that the hypocalcemic activity observed was due to calcitonin and not to some other unknown agent. However, the possibility that ovine calcitonin has an amino acid composition different than porcine calcitonin should be considered, since human calcitonin has been found to have many amino acid residues which are not found in the porcine hormone (Neher et al. 1968). The possibility that calcitonin can be synthesized in an in vitro system opens the way for further studies. The hormone with a radioactive label can be used to trace the locus of action at the cellular level at the target organs. The mechanism and the site of synthesis can be studied by the use of protein synthesis inhibitors and cellular fractionation. Since the hormone is present in granules in the C cells it would be of interest to study the locus of synthesis and the transport of the hormone to the granules. Another aspect of calcitonin synthesis amenable to study with the system developed in this investigation is whether the hormone is synthesized as a 32 amino acid polypeptide or whether it has a precursor molecule, and if so, when and how it is transformed into the biologically active polypeptide which is found in the thyroid glands. 


\section{$-86-$ \\ CHAPTER V \\ SUMMARY AND CONCLUSIONS}

Recently the in vitro biosynthesis of polypeptide hormones has been reported. In this investigation was presented a method for the biosynthesis of calcitonin in ovine thyroid slices. Ovine thyroid tissue is contaminated with the inferior parathyroid tissue, whereas the superior parathyroids are anatomically separated. We did not attempt to separate the parathyroid tissue, since the calcitonin synthesizing cells are "adventitious" to the thyroid and in some species to the parathyroids and thymus (MacIntyre, 1968); furthermore, since it is now well established that there is only one calcitonin it was thought that if the sheep parathyroid tissue contained $C$ cells the calcitonin synthesized by these cells would not interfere with the purpose of our work. The biosynthesis of the hormone opens the way for studies on the mechanism and control of synthesis and release of the hormone.

In this study it was attempted to establish the role played by calcium in the regulation of synthesis and release of calcitonin. It has been shown that in vivo calcitonin increases in the serum of animals in response to a hypercalcemic stimulus. In vivo studies, however, cannot discern whether the hypercalcemia increases synthesis, release or both. The results presented in this investigation show that calcium increases 
both the synthesis and release of the hormone. Other factors may exist, and recently Avioli et al. (1968) has found evidence that glucagon may release calcitonin from the thyroid glands. If this is true the effect of glucagon is probably not related to the calcium effect, since calcium can act in vitro, and the effect is a specific property of the calcium ion. In fact, magnesium cannot substitute for calcium. This may have been anticipated since calcitonin does not affect magnesium levels in the blood (Gitelman et al. 1965).

The purified hormone was found to have very high specific activity, approximately $67 \mathrm{MRC}$ units per milligram protein. The hormone was found to be pure and homogenous by thin layer chromatography and amino acid analysis. 


\section{BIBLIOGRAPHY}

1. Adiga, P. R., I. Uemura, and T. Winnick (1965). Biosynthesis of Adrenocorticotropin and Protein in Slices of Bovine Anterior Pituitary Tissue. Biochemistry 4, 246-252.

2. Aer, T. (1968). Effect of Thyrocalcitonin on Urinary Hydroxyproline and Calcium in Rats. Endocrinology 83, 379-380.

3. Albright, F. and Reifenstein, E. C. (1948). The Parathyroid Glands and Metabolic Bone Disease, The Williams and Wilkins Co., Baltimore, pp. 13-23.

4. Alcock, N. and MacIntyre, I. (1962). Inter-Relation of Calcium and Magnesium Absorption. Clin. Sci. 22, 185-193.

5. Aliapoulios, M. A., Goldhaber, P.; and Munson, P. L. (1966). Thyrocalcitonin Inhibition of Bone Resorption by Parathyroid Hormone in Tissue Culture. Science 151, 330-331.

6. Aliapoulios, M. A., Voelkel, E. F., and Munson, P. L. (1966). Assay of Human Thyroid Glands for Thyrocalcitonin Activity. J. Clin. Endocrinol. and Metabolism 26, 897-901.

7. Ashby, R. D. and Roberts, M. (1957). A Microdetermination of Calcium in Blood Serum. J. L. Clin. Med. 49, 958-961.

8. Avioli, L. V., Birge, S., and Scott, S. Unpublished Observations. Cited in Foster, G. V. (1968). Calcitonin (Thyrocalcitonin). New Engl. J. Med. 279, 349-360.

9. Barrett, R. J., Bell, N. H., Stern, H. P., and Schlueter, R. J. (1968). Extraction, Partial Purification and Demonstration of Biological Activity of Human Thyrocalcitonin. J. Clin. Endocrinol. and Metabolism 28, 734-739.

10. Bauer, G. E. and Lazarow, A. (1961). Studies on the Isolated Islet Tissue of Fish. In Vitro Incorporation of $\mathrm{C}^{14}$ and $\mathrm{H}^{3}$ Labeled Amino Acids into Goosefish Islet Tissue Proteins. Biol. Bull. 121, 425-437. 
11. Baylink, D., Morey, E., and Rich, C. (1969). Effect of Calcitonin on the Rates of Bone Formation and Resorption in the Rat. Endocrinology 84, 261-269.

12. Bell, N. H., Barrett, R. J., and Patterson, R. (1966). Effects of Porcine Thyrocalcitonin on Serum Calcium, Phosphorus and Magnesium in the Monkey and in Man. Proc. Soc. Exp. Biol. Med. 123, 114-118.

13. Bethune, J. E., Turpin, R. A., and Inoue, H. (1968). Effect of Parathyroid Hormone Extract on Divalent Ion Excretion in Man. J. Clin. Endocrinol. and Metabolism 28, 673-678.

14. Bexter, E., Fraser, J. R. E., Harris, G. S., Martin, T. J., and Melick, R. A. (1968). Stimulation of Glycosaminoglycan Synthesis by Thyrocalcitonin Preparations. Med. J. Australia 1. 216-217.

15. Bijvoet, O. L. M. and Jansen, A. P. (1967). Thyrocalcitonin in Paget's Disease. Lancet $2,471-472$.

16. Blaxter, K. L. (1956). The Magnesium Content of Bone in Hypomagnesimic Disorders of Livestock. In "Bone Structure and Metabolism" (G. W. Wolstenholme and C. M. O'Connor, eds.), p. 117, Little, Brown and Co., Boston.

17. Brewer, H. B., Jr., Keutmann, H. T., Reisfeld, R. A., Schlueter, R., Munson, P. L. and Potts, J. T., Jr. (1968). Role of Sulfur Containing Amino Acids in the Biological Activity of Porcine Thyrocalcitonin. Federation Proc. 27, 690.

18. Bussolati, G., Carvalheira, A. F. and Pearse, A. G. E. (1967). Immunofluorescence Studies on the Source of Calcitonin and the Effect of Immunization with Calcitonin on the Thyroid Gland of the Guinea-pig. In "Calcitonin" (S. Taylor, ed.), p. 133, Springer-Verlag, Inc., New York.

19. Buckle, R. M. and Care, A. D. (1967). Unpublished Observations. Cited in "Parathyroid Hormone and Thyrocalcitonin (Calcitonin)" (R. V. Talmage and L. F. Belanger, eds.), p. 408, Excerpta Medica Foundation, Amsterdam-C, The Netherlands. 
20. Care, A. D., Duncan, T., and Webster, D. (1967). Thyrocalcitonin and Its Role in Calcium Homeostasis. J. Endocrinol. 37, 155-167.

21. Care, A. D., Cooper, C. W., Duncan, T., and Orimo, H. (1968). A Study of Thyrocalcitonin Secretion by Direct Measurement of In Vivo Secretion Rates in Pigs. Endocrinology 83, 161-169.

22. Cartier, P. (1951). Biochimie de l'Ossification: le Role de l'Acide Adenosine Triphosphirique dans la Mineralisation du Cartilage Ossifiable. J. Physiol. (Paris), 43, 668-677.

23. Carvalheira, A. F. and Pearse, A. G. E. (1967). Cytochemical Evidence for the Ultimobranchial Origin of the C Cells in Rodent Thyroid. In "Calcitonin" (S. Taylor, ed.), p. 122, Springer-Verlag, Inc., New York.

24. Chase, L. R. and Aurbach, G. D. (1967). Parathyroid Function and the Renal Excretion of 3' 5' Adenylic Acid. Proc. Nat. Acad. Sci. U.S. 58, 518-525.

25. Chase, L. R. and Aurbach, G. D. (1968). Activation of Skeletal Adenyl Cyclase by Parathyroid Hormone in Vitro. Third Inter. Congress Endocrinol. Section 44 ( $\overline{\mathrm{Ab}} \overline{\text { stract }}$ No. 218).

26. Chase, L. R. and Aurbach, G. D. (1968). Renal Adenyl Cyclase: Anatomically Separate Sites for Parathyroid Hormone and Vasopressin. Science 159, 545-547.

27. Clark, I. and Geoffrey, R. (1958). Studies on Calcium Metabolism. J. Biol. Chem. 233, 203-205.

28. Clark, N. B. (1968). Calcitonin Studies in Turtles. Endocrinology $83,1145-1148$.

29. Collip, J. B. (1925). The Extraction of a Parathyroid Hormone which will Prevent or Control Parathyroid Tetany and which Regulates the Level of Blood Calcium. J. Biol. Chem. 63, $395-438$.

30. Collip, J. B., Clark, E. P., and Scott, J. W. (1925). The 
Effect of a Parathyroid Hormone on Normal Animals. J. Biol. Chem. 63, 439-460.

31. Collip, J. B. and Clark, E. P. (1925). Further Studies on the Parathyroid Hormone. J. Biol. Chem. 66, 133-137.

32. Collip, J. B. and Clark, E. P. (1925). Further Studies on the Physiological Action of a Parathyroid Hormone. J. Biol. Chem. 64, 485-507.

33. Copp, D. H. and Davidson, A. G. F. (1961). Direct Humoral Control of Parathyroid Function in the Dog. Proc. Soc. Exp. Biol. Med. 107, 342-344.

34. Copp, D. H. and Davidson, A. G. F. and Cheney, B. A. (1961). Evidence for a New Parathyroid Hormone which Lowers Blood Calcium. Proc. Can. Fed. Biol. Soc. 4 , 17.

35. Copp, D. H., Cameron, E. C., Cheney, B. A., Davidson, A. G. F. and Heuze, K. G. (1962). Evidence for Calcitonin. A New Hormone from the Parathyroid that Lowers Blood Calcium. Endocrinology 70, 638-649.

36. Copp, D. H., Cochcroft, D. W., Dueh, L. and Melville, M. (1967). Calcitonin--Ultimobranchial Hormone. In "Calcitonin" (S. Taylor, ed.), p. 306, Springer-Verlag, Inc., New York.

37. Cunliffe, W. J., Black, M. M., Hall, R., Johnston, I. D. A., Hudgson, P., Shuster, S., Gudmundsson, T. V., Joplin, G. F., Williams, E. D., Woodhouse, N. J. Y., Galante, L., and MacIntyre, I. (1968). Calcitonin-Secreting Thyroid Carcinoma. Lancet 2, 63-66.

38. Doty, S. B., Schofield, B. H. and Robinson, R. A. (1968). The Electron Microscope Identification of Acid Phosphatase and Adenosinetriphosphatase in Bone Cells Following Parathyroid Extract or Thyrocalcitonin Administration. In "Parathyroid Hormone and Thyrocalcitonin (Calcitonin)" (R. V. Talmage and L. F. Belanger, eds.), p. 169, Excerpta Medica Foundation, Amsterdam-C, The Netherlands.

39. Deftos, L. J., Lee, M. R., and Potts, J. T., Jr. (1968). A 
Radioimmunoassay for Thyrocalcitonin. Proc. Nat. Acad. Sci. U.S. 60, 293-299.

40. Foster, G. V. (1966). Thyrocalcitonin: Failure to Demonstrate Parathyroid Releasing Factor. Nature 211, 1319-1320.

41. Foster, G. V., Bagdaintz, A., Kumar, M. A., Slack, E., Soliman, H. A., and MacIntyre, I. (1964). The Thyroid Origin of Calcitonin. Nature 202, 1303-1305.

42. Foster, G. V., Clark, M. G., Doyle, F. H., Joplin, G. F., Singer, F. R., Frazer, T. R. and MacIntyre, I. (1968). Clinical Applications of Calcitonin. In "Parathyroid Hormone and Thyrocalcitonin (Calcitonin)" (R. $\bar{V}$. Talmage and L. F. Belanger, eds.), p. 100, Excerpta Medica Foundation, Amsterdam-C, The Netherlands.

43. Foster, G. V., Gudmundsson, T. V., Joplin, G. F., Martin, T. J., Melvin, D. E. W., Thalassinos, N., Frazer, T. R., and MacIntyre, I. (1967). Calcitonin: Studies in Man. In "Calcitonin" (S. Taylor, ed.), p. 379, Springer-Verlag, Inc., New York.

44. Foster, G. V., Joplin, G. F., MacIntyre, I., Melvin, D. E. W., and Stock, E. (1966). The Effect of Thyrocalcitonin in Man. Lancet 1, 107-109.

45. Foster, G. V., MacIntyre, I., and Pearse, A. G. E. (1964). Calcitonin Production and the Mitochondrion-rich Cells of the Dog Thyroid. Nature 203, 1029-1030.

46. Friedman, J. and Raisz, L. G. (1965). Thyrocalcitonin: Inhibitor of Bone Resorption in Tissue Culture. Science 150, 1465-1467.

47. Gaillard, P. J. (1967). Bone Culture Studies with Thyrocalcitonin. Konink. Ned. Akad. Wetenschap. Proc. Ser. C. 70, 309-320.

48. Gaillard, P. J. and Thesingh, C. W. (1967). Bone Culture Studies with Thyrocalcitonin. In "Calcitonin" (S. Taylor, ed.), p. 238, Springer-Verlag, Inc., New York.

49. Gittes, R. F. and Irvin, G. L. (1965). Thyroid and Parathyroid 
Roles in Hypercalcemia: Evidence for Thyrocalcitonin-Releasing Factor. Science 148, 1737-1739.

50. Gittes, R. F., Toverud, S. U., and Cooper, C. W. (1968). Effects of Hypercalcemia and Hypocalcemia on Thyrocalcitonin Content of Rat Thyroid Glands. Endocrinology 82, 83-90.

51. Gitelman, H., Kukolj, S., and Welt, L. G. (1965). Effect of Thyrocalcitonin on the Partition of Plasma Calcium. Clin. Res. 13, 323.

52. Goldhaber, P., Stern, B. D., Glimcher, M. J., and Chao, J. (1968). The Effects of Parathyroid Extract and Thyrocalcitonin on Bone Remodeling in Tissue Culture. In "Parathyroid Hormone and Thyrocalcitonin (Calcitonin)" (R. V. Talmage and L. F. Belanger, eds.), p. 182, Excerpta Medica Foundation, Amsterdam-C, The Netherlands.

53. Gudmundsson, T. V., Byfield, P. G. H., Galante, L., and MacIntyre, I. (1968). The Purification of Calcitonin. In "Calcitonin" (S. Taylor, ed.), p. 51, Springer-Verlag, Inc., New York.

54. Gudmundsson, T. V., MacIntyre, I. , and Soliman, H. A. (1966). Isolation of Thyrocalcitonin and Study of Its Effects in Rats. Proc. Roy. Soc. (London) B $164,460-477$.

55. Hendrix, J. A., Alcock, N. W., and Archibald, R. M. (1963). Comparison Between $\mathrm{Ca}, \mathrm{Sr}$, and $\mathrm{Mg}$ for Absorption in the Isolated Rat Intestine. Clin. Chem. 9, 734-744.

56. Hirsch, P. E., Gauthier, G., and Munson, P. L. (1963). Thyroid Hypocalcemic Principle and Recurrent Laryngeal Nerve Injury as Factors Affecting the Response to Parathyroidectomy in Rats. Endocrinology 73, 244-252.

57. Hirsch, P. E. and Munson, P. L. (1966). Importance of the Thyroid Gland in the Prevention of Hypercalcemia in Rats. Endocrinology 79, 655-658.

58. Hirsch, P. E., Voelkel, E. F., and Munson, P. L. (1964). 
Thyrocalcitonin: Hypocalcemic Hypophosphatemic Principle of the Thyroid Gland. Science 146, 412-413.

59. Johnston, C. C., Jr. and Deiss, W. P., Jr. (1966). An Inhibitory Effect of Thyrocalcitonin on Calcium Release In Vivo and Bone Metabolism In Vitro. Endocrinology $78,1139-1143$.

60. Kahnt, F. W., Riniker, B., MacIntyre, I., and Neher, R. (1968). Thyrocalcitonin. I. Isolierung und Charakterisierungwirksamer Peptide aus Schweineschilddrusen. Helv. Chim. Acta 51, 214-217.

61. Kenny, A. D. (1964). In "Discussion of Copp, D. H. Parathyroids, Calcitonin and Control of Plasma Calcium". Recent Progress in Hormone Research $20,84$.

62. Kenny, A. D. and Heishell, C. A. (1965). Effect of Crude Thyrocalcitonin on Calcium and Phosphor us Metabolism in Rats. Proc. Soc. Exp. Biol. Med. 120, 269-271.

63. Klein, C. D. and Talmage, R. V. (1967). Effects of Hog Thyrocalcitonin on Circulating Levels of Hydroxyproline in the Rat. Federation Proc. 26, 368.

64. Kumar, M. A., Slack, E., Edwards, A., Soliman, H. A., Bagdiantz, A., Foster, G. V., and MacIntyre, I. (1965). A Biological Assay for Calcitonin. J. Endocrinol. 33, 469-475.

65. Lee, M. R., Deftos, L. J., and Potts, J. T., Jr. (1969). Control of Secretion of Thyrocalcitonin in the Rabbit as Evaluated by Radioimmunoassay. Endocrinology 84, 36-40.

66. Lowry, O. H., Rosebrough, N. J., Farr, A. L., and Randall, R. J. (1951). Protein Measurement with the Folin Phenol Reagent. J. Biol. Chem. 193, 265-275.

67. MacCallum, W. G. (1909). On the Relation of Tetany to the Parathyroid Glands and to Calcium Metabolism. J. Exp. Med. 2, 118-151.

68. MacCallum, W. G. and Voegtlin, C. (1908). On the Relation of the Parathyroid to Calcium Metabolism and the Nature of 
Tetany. Bull. Johns Hopkins Hosp. 19, 91-92.

69. MacIntyre, I. (1968). Calcitonin: Some Recent Advances. In Proceedings of the Third International Congress of Endocrinology. Amsterdam-C, The Netherlands, Excerpta Medica Foundation.

70. MacIntyre, I., Foster, G. V., and Kumar, M. A. (1965). The Thyroid Origin of Calcitonin. In "The Parathyroid Glands". (P. J. Gaillard, R. V. Talmage, and A. M. Budy, eds.), p. 89, The University of Chicago Press, Chicago.

71. MacIntyre, I., Parsons, J. A., and Robinson, C. J. (1967). The Effect of Thyrocalcitonin on the Blood-bone Calcium Equilibrium in the Perfused Tibia of the Cat. J. Physiol. (London) 191, 393-405.

72. Mallory, A., Smith, G. H., and Taylor, K. W. (1964). The Incorporation of ${ }^{3} \mathrm{H}$-Labeled. Amino Acids into Insulins in Rat Pancreas in Vitro. Biochem. J. 91, 484-491.

73. Martin, T. J., Robinson, C. J., and MacIntyre, I. (1966). The Mode of Action of Thyrocalcitonin. Lancet 1, 900-902.

74. Matrajt, H., Bordier, P., Tun-Chot, S., Hioco, D., Foster, G. V., and Doyle, F. H. (1967). Histological Bone Changes Produced by Calcitonin. In "Calcitonin" (S. Taylor, ed.), p. 338, Springer-Verlag, Inc., New York.

75. Matsuzawa, T. and Kurosumi, K. (1967). Morphological Changes in Parafollicular Cells of Rat Thyroid Glands After Administration of Calcium Shown by Electron Microscopy. Nature 213, 927-928.

76. Mazzuoli, G. F., Coen, G., and Antonozzi, T. (1966). Thyrocalcitonin Excess Syndrome. Lancet 2, 1192-1193.

77. McLean, F.C. and Hastings, A. B. (1935). Clinical Estimation and Significance of Calcium-ion Concentration in the Blood. Am. J. Med. Sci. 189, 601-613.

78. McLean, F. C. and Urist, M. R. (1955). Bone. The University of Chicago Press, Chicago and London, Chapter X. 
79. Melvin, K. E. W., and Tashjian, A. H., Jr. (1968). Syndrome of Excessive Thyrocalcitonin Produced by Medullary Carcinoma of Thyroid. Proc. Nat. Acad. Sci. U.S. 59, 1216-1222.

80. Milhaud, G. and Moukhtar, M. S. (1965). Hypophysectomy et Thyrocalcitonine. Compt. Rend. 260, 3179-3182.

81. Milhaud, G., Moukhtar, M. S., Cherion, G., and Perault, A. M. (1966). Effect de l'Administration de Thyrocalcitonine sur les Principaux Parometres du Metabolism du Calcium du Rat Normal et du Rat Thyroparathyroidectomisé. Compt. Rend. 262, $511-514$.

82. Milhaud, G., Moukhtar, M. S., Perault, A. M., and Bourichon, J. (1965). Existence et Activité de la Thyrocalcitonine chez I'Homme. Compt. Rend. 261, 4513-4516.

83. Milhaud, G., Perault, A. M., ând Moukhtar, M. S. (1965b). Étude du Mécanisme de l'Action Hypocalcémiante de la Thyrocalcitonine. Compt. Rend. 261, 813-816.

84. Milhaud, G., Tubiana, M., Parmentier, C., and Coutris, G. (1968). Epithelioma de la Thyroide Secretant de la Thyrocalcitonine. Compt. Rend. 266, 608-610.

85. Moseley, J. M., Matthews, E. W., Breed, R. H., Galante, L., Tse, A., and MacIntyre, I. (1968). The Ultimobranchial Origin of Calcitonin. Lancet 1, 108-110.

86. Neher, R., Riniker, B., Rittel, W., and Zuber, H. (1968). Menschliches Calcitonin. III. Struktur von Calcitonin M und D. Helv. Chim. Acta 51, 1900-1905.

87. Neher, R., Riniker, B., Zuber, H., Rittel, W, and Kalmt, F. W. (1968). Thyrocalcitonin. II. Struktur von a-Thyrocalcitonin. Helv. Chim. Acta 51, 917-924.

88. Nonidez, J. F. (1932). Further Observations on the Parafollicular Cells of the Mammalian Thyroid. Anat. Record 53, 339-354.

89. Nordin, B. E. C. (1966). Hormones and Calcium Metabolism. In "Calcified Tissues 1965". Proc. of the Third European 
Symposium on Calcified Tissues. (H. Fleisch, H. J. J. Blackwood and M. Owen, eds.), p. 237.

90. Oyama, V. I. and Eagle, H. (1956). Measurement of Cell

Growth in Tissue Culture with Phenol Reagent. Proc. Soc.

Exp. Biol. Med. 91, 305-307.

91. Parsons, J. A. (1967). Effects of Added Proteins on Apparent Potency of Thyrocalcitonin. In "Calcitonin" (S. Taylor, ed.), p. 35, Springer-Verlag, Inc., New York.

92. Parsons, J. A. and Reynolds, J. J. (1968). Species Discrimination Between Calcitonins. Lancet 1, 1067-1070.

93. Pearse, A. G. E. (1965). The Enzyme Systems of the Mammalian Parathyroid with a Note on Calcitonin Production. In "The Parathyroid Glands" (P. J. Gaillard, R. V. Talmage and A. M. Budy, eds.), p. 27, The University of Chicago Press, Chicago.

94. Pearse, A. G. E. (1966). The Cytochemistry of the Thyroid C Cells and Their Relationship to Calcitonin. Proc. Roy. Soc. (London) B 164, 478-487.

95. Potts, J. T., Jr., Niall, H. D., Keutmann, H. T., Brewer, H. B., Jr., and Deftos, L. J. (1968). Amino Acid Sequence of Porcine Thyrocalcitonin. Proc. Nat. Acad. Sci. U.S. 59, 1321-1328.

96. Potts, J. T., Jr., Reisfeld, R. A., Hirsch, P. F., Wasthed, A. B., and Munson, P. L. (1967). Purification and Chemical Properties of Porcine Thyrocalcitonin. In "Calcitonin" (S. Taylor, ed.), p. 63, Springer-Verlag, Inc, , New York.

97. Potts, J. T., Jr., Reisfeld, R. A., Hirsch, P. F., Wasthed, A. B., Voelke1, E. F., and Munson, P. L. (1967). Purification of Porcine Thyrocalcitonin. Proc. Nat. Acad. Sci. U.S. 58, $328-335$.

98. Raisz, L. G., Au, W. Y. W., Friedman, J., and Nieman, I. (1967). Inhibition of Bone Resorption in Tissue Culture by Thyrocalcitonin. In "Calcitonin" (S. Taylor, ed.), p. 215, 
Springer-Verlag, Inc., New York.

99. Raisz, L. G. and Niemann, J. (1967). Early Effects of Parathyroid Hormone and Thyrocalcitonin on Bone in Organ Culture. Nature 214, 486-487.

100. Raisz, L. G. and O'Brien, J. E. (1963). Effect of Calcium on the Uptake of a-Aminoisobutyric Acid by Parathyroid Glands. Am. J. Physiol. 205, 816-820.

101. Rasmussen, H. (1959). The Stability in Vitro of Parathormone B. J. Biol. Chem. 234, 547-550.

102. Rasmussen, H. (1961). Parathyroid Hormone. Am. J. Med. 30, $112-128$.

103. Rasmussen, H., Sze, Y., and Young, R. (1964). Further Studies on the Isolation and Characterization of Parathyroid Polypeptides. J. Biol. Chem. 239, 2852-2857.

104. Rittel, W., Brugger, M., Kamber, B., and Sieber, P. (1968). Thyrocalcitonin. III. Die Synthese des a-Thyrocalcitonine. Helv. Chim. Acta 51, 924-928.

105. Reynolds, J. J., Dingle, J. T., Gudmundsson, T. V., and MacIntyre, I. (1967). Bone Resorption in Vitro and Its Inhibition by Calcitonin. In "Calcitonin" (S. Taylor, ed.), p. 223, Springer-Verlag, Inc., New York.

106. Robinson, C. J., Martin, T. J., and MacIntyre, I. (1966). Phosphaturic Effect of Thyrocalcitonin. Lancet $\underline{2}$, 83-84.

107. Robinson, C. J., Martin, T. J., Matthews, E. W., and MacIntyre, I. (1967). Mode of Action of Thyrocalcitonin. J. Endocrinol. 39, $71-79$.

108. Russell, R. G. G. and Fleisch, H. (1967). The Renal Effects of Thyrocalcitonin in the Pig and Dog. In "Calcitonin" (S. Taylor, ed.), p. 297, Springer-Verlag, Inc., New York.

109. Sachs, H. (1963). Vasopressin Biosynthesis: Incorporation of ${ }^{35} \mathrm{~S}$-cysteine into Vasopressin and Protein Associated with Cell 
Fractions: J. Neurochem. 10, 299-311.

110. Sanderson, P. H., Marshall, F., and Wilson, R. E. (1960).

Calcium and Phosphorus Homeostasis in Parathyroidectomized Dogs: Evaluation by Means of EDTA and Calcium Tolerance Tests. J. Clin. Invest. 39, 662-670.

111. Schachter, D. and Rosen, S. M. (1959). Active Transport of $\mathrm{Ca}^{45}$ by the Small Intestine and Its Dependence on Vitamin D. Am. J. Physiol. 196, 357-362.

112. Sherwood, L. M., Mayer, G. S., Ramberg, C. F., Jr., Kronfeld, D. S., Aurbach, G. D. and Potts, J. T., Jr. (1968). Regulation of Parathyroid Hormone Secretion: Proportional Control by Calcium, Lack of Effect of Phosphate. Endocrinology 83, 1043-1051.

113. Stahl, P. D., Clark, J. D., Waite, L. C., and Kenny, A. D. (1966). Effect of Crude Thyrocalcitonin in the Dog. Federation Proc. 25, 496.

114. Stahl, P. D. and Kenny, A. D. (1967). Thyrocalcitonin in the Dog. Serum Calcium and Phosphorus Responses. Endocrinology 81, $661-665$.

115. Steiner, D. F., Cunningham, D., Spigelman, L., and Aten, B. (1967). Insulin Biosynthesis: Evidence for a Precursor. Science 157, 697-700.

116. Talmage, R. V., Neuenschwander, J., and Kraintz, L. (1965). Evidence for Thyrocalcitonin Secretion in the Rat. Endocrinology 76, 103-107.

117. Takabatake, $Y$. and H. Sachs (1964). Vasopressin Biosynthesis. III. In Vitro Studies. Endocrinology 75, 934-942.

118. Tashjian, A. H., Jr. (1965). Homeostasis of Plasma Calcium: Effects of Actinomycin D, Parathyroidectomy and Thyrocalcitonin. Endocrinology 77, 375-381.

119. Tashjian, A. H., Jr., Frantz, A. G., and Lee, J. B. (1966). Pseudohypoparathyroidism: Assay of Parathyroid Hormone and 
Thyrocalcitonin. Proc. Nat. Acad. Sci. U.S. 56, 1138-1142.

120. Tashjian, A. H., Jr., and Munson, P. L. (1965). Antibodies to Porcine Thyrocalcitonin: Effects of Hypocalcemic Activity of Calf, Rat and Monkey Thyroid Extracts. Endocrinology 77, 520528.

121. Toverud, S. U., Gittes, R. F., and Munson, P. L. (1966). Thyroid and Parathyroid Glands in Recovery from Hypocalcemia. Federation Proc. 25, 347.

122. Wakabayashi, K., Tomaoki, B., and Kukushima, M. (1965). In Vitro Biosynthesis of Luteinizing Hormone in the Anterior Pituitary Glands. Endocrinology 77, 264-272.

123. Wells, H. and Lloyd, W. (1967). Effects of Theophylline on the Serum Calcium of Rats After Parathyroidectomy and Administration of Parathyroid Hormone. Endocrinology 81, 139-144.

124. Wells, H. and Lloyd, W. (1968a). Hypocalcemic Effect of Imidazole in Rats. Endocrinology 83, 521-529.

125. Wells, H. and Lloyd, W. (1968b). Possible Involvement of Cyclic AMP in the Actions of Thyrocalcitonin and Parathyroid Hormone. In "Parathyroid Hormone and Thyrocalcitonin (Calcitonin)" (R. V. Talmage and L. F. Belanger, eds.), p. 332, Excerpta Medica Foundation, Amsterdam-C, The Netherlands.

126. Wool, I. G., Scharff, R., and Mage, N. (1961). In Vitro Synthesis of $\mathrm{C}^{14}$-Corticotropin by Isolated Rat Anterior Pituitary: Effect of Adrenalectomy. Am. J. Physiol. 201, 547-550. 


\section{ABSTRACT}

Abstract of the dissertation entitled "THE IN VITRO BIOSYNTHESIS OF CALCITONIN" submitted by Nino Sorgente in partial fulfillment of the requirements for the degree of Doctor of Philosophy, June, 1969.

Slices of ovine thyroid glands were incubated $\left(4 \mathrm{hr}, 37^{\circ} \mathrm{C}\right)$ with glycine-C-14 in Krebs-Ringer bicarbonate buffer $(\mathrm{pH}$ 7.4) containing glucose $(320 \mathrm{mg} / 100 \mathrm{ml})$ and the amino acids of calcitonin $(20 \mathrm{mg} / 1)$. Calcitonin was isolated by sodium chloride precipitation from the incubated slices, and the hypocalcemic activity assayed in 140-170 gram rats fasted for 18 hours. The hypocalcemic activity was expressed as the change in serum calcium between time 0 and 50 minutes per 10 or $25 \mu \mathrm{g}$ protein of the calcitonin preparation.

The hypocalcemic activity of calcitonin isolated from glands incubated in buffer containing physiological concentrations of calcium (11.5 $\mathrm{mg} \%$ ) was not significantly different from the hypocalcemic activity of calcitonin isolated from unincubated glands. However, when the hypocalcemic activity of calcitonin isolated from slices incubated in buffer containing high concentrations of calcium $(45.6 \mathrm{mg} \%$ was compared to the hypocalcemic activity of calcitonin isolated from slices incubated in buffer containing physiological concentrations of calcium, it was found that the hypocalcemic activity increased 50\%. An increase 
in the magnesium concentration of the buffer from $3.7 \mathrm{mg} \%$ to $29.8 \mathrm{mg} \%$ had no significant effect on the hypocalcemic activity of the calcitonin preparations.

To determine whether calcium had an effect on the release of calcitonin from the glands, at the end of the incubation the media was assayed for hypocalcemic activity. A significant increase in hypocalcemic activity was found in the incubation media containing high concentrations of calcium as compared to the media containing physiological concentrations of calcium.

The calcitonin from incubated slices was isolated by sodium chloride precipitation and purified by passage of the isolated material on columns of Sephadex G-100 and Sephadex G-50 superfine. The purified material was homogeneous on thin layer chromatography and contained very high hypocalcemic activity (66.5 MRC units per milligram protein). The purified material was subjected to amino acid analysis, and it was found to contain all amino acids of porcine calcitonin, except leucine, phenylalanine and tyrosine. The glycine peak was collected and was found to contain radioactivity.

In this work, a method for the biosynthesis of calcitonin in ovine thyroid slices was developed. Using this method it has been shown that both the synthesis and release of calcitonin are under the control of calcium ions. Magnesium ions cannot substitute for calcium to stimulate the synthesis of calcitonin. 
APPROVAL SHEET

The dissertation submitted by Wino Sorgente has been read and approved by a committee from the faculty of the Graduate School.

The final copies have been examined by the director of the dissertation and the signature which appears below verifies the fact that any necessary changes have been incorporated, and that the dissertation is now given final approval with reference to content, form and mechanical accuracy.

The dissertation is therefore accepted in partial fulfillment of the requirements for the Degree of Doctor of Philosophy.

$\operatorname{may} 26,1969$

Date

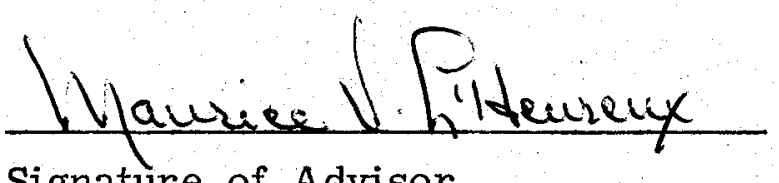

Signature of Advisor 